\title{
Seasonal deepening of the pycnocline in a shallow shelf ecosystem and its influence on near-bottom dissolved oxygen
}

\author{
John R. Kelly ${ }^{1, *}$, Peter H. Doering ${ }^{2}$ \\ ${ }^{1} 3$ Willow Lane, Rye, New Hampshire 03870, USA \\ ${ }^{2}$ South Florida Water Management District, 3301 Gun Club Road, West Palm Beach, Florida 33416-4680, USA
}

\begin{abstract}
A 3 yr record (1992 to 1994) of dissolved oxygen (DO) concentrations from an intensive grid of 21 sampling stations in a $\sim 100 \mathrm{~km}^{2}$ study area of western Massachusetts Bay ( 25 to $50 \mathrm{~m}$ water depth) showed a regular seasonal decline in bottom waters during stratification, but considerable spatial and temporal variability within and across years. Mean near-bottom, subpycnocline DO concentrations for the area reached 7.57, 7.85, and $6.2 \mathrm{mg} \mathrm{l}^{-1}$ in mid October 1992, late September 1993, and late September 1994, respectively; individual station readings were as low as $4.8 \mathrm{mg} \mathrm{l}^{-1}$ in 1994 . Overall stratified-season rates of subpycnocline DO decline were -0.025 to $0.031 \mathrm{mg} \mathrm{l}^{-1} \mathrm{~d}^{-1}$, but rates increased late in the season as the bottom layer sharply warmed to its annual temperature maximum. Concurrent with relatively lower DO concentrations in 1994, field measurements indicated high bottom-water temperatures $>12^{\circ} \mathrm{C}\left(\geq 4^{\circ} \mathrm{C}\right.$ above 1992 to 1993$)$ and a deepened pycnocline just prior to overturn. To address how factors like temperature and vertical structure of the water column interact with metabolic processes to shape observed trends in DO decline and spatio-temporal variability, we used a simple model with physical and biological measurements from field monitoring as inputs. From field and model sensitivity results, we conclude that temperature and stratification strongly influence DO minima and rates of decline, and these factors interact with the bathymetric slope, as well as the topographic and depositional heterogeneity of the study area, to create subpycnocline variability in DO. With respect to lower DO in 1994, temperature contributed by accelerating both water and sediment metabolism, but a major effect was the late-season deepening of the pycnocline that enhanced the contribution of sediment respiration to DO decline by isolating a thin near-bottom water layer. In addition, dynamics of seasonal pycnocline deepening are a principal influence on interannual variability in bottom-water DO because, in contrast to the late-season effect, early in the stratified season a shallow pycnocline depth may moderate DO decline by allowing mid-water primary production to add DO to subpycnocline water
\end{abstract}

KEY WORDS: Dissolved oxygen - Metabolism S Stratification Pycnocline - Massachusetts Bay

\section{INTRODUCTION}

Many factors influence the concentration of dissolved oxygen (DO) in near-bottom waters of shallow temperate coastal ecosystems. Flushing and stratification, pelagic metabolism and benthic processes, as well as allochthonous inputs from inshore waters help

\footnotetext{
- Present address: U.S. EPA, Mid-Continent Ecology Division, 6201 Congdon Blvd., Duluth, Minnesota 55804, USA.

E-mail: kelly.johnr@epa.gov
}

set DO levels in many areas (e.g. Falkowski et al. 1980 Officer et al. 1984, Parker \& O'Reilly 1991, Welsh \& Eller 1991, Stanley \& Nixon 1992, Torgersen et al. 1997). In our study area in western Massachusetts Bay (MA, USA), an offshore submarine outfall ( $\sim 32 \mathrm{~m}$ water depth) will be operational soon, discharging treated effluent into subpycnocline layers. A long-term water quality monitoring program of Massachusetts Bay has been developed related to the outfall. The baseline monitoring period prior to discharge provides an extensive data set to examine dynamics of DO in rela- 
tion to various physical and biological factors that presently influence these Massachusetts Bay bottom waters.

Using monitoring data for 3 annual cycles, this paper reports a number of trends in DO concentrations, temperature, and physical structure of the water column for an intensively studied $\sim 100 \mathrm{~km}^{2}$ region in western Massachusetts Bay. Examples from the extensive data set emphasize inter-annual differences, as well as finescale heterogeneity in bottom-water DO during the stratified season when annual DO minima occur, typically late September to early November. Moreover, monitoring results on temperature and water column structure are used to drive a simple model, which also uses results from water column and sediment respiration measurements made during relatively intensive studies of 1993-1994, to predict bottom-water DO decline during seasonal stratification.

Results of the field observations and modeling efforts are combined in this paper to address a central question: what influences DO concentrations, seasonal decline rates, and the development of DO minima in near-bottom waters of this near-shore shelf region? The region is enriched by coastal nutrient exports (Kelly 1997) and primary production rates are 400 to $600 \mathrm{gC} \mathrm{m}^{-2} \mathrm{yr}^{-1}$ (Kelly \& Doering 1997), eutrophic to hypertrophic by Nixon's (1995) proposed classification. Nonetheless, during the early 1990 period, DO concentration minima did not tend towards hypoxia (or anoxia), unlike some US coast shelf-water or estuarine areas also adjacent to major coastal populations (e.g Long Island Sound, New York Bight, Chesapeake Bay) or enclosed coastal seas that have increasing nutrient inputs and a long water residence time (e.g. the Baltic). Even so, stratification, as in other areas, promotes a seasonal decline in western Massachusetts Bay's subpycnocline DO. Our study identifies a dimension and dynamic of stratification that has not been strongly emphasized in the literature: the seasonally progressive deepening of the pycnocline plays a substantial role in creating near-bottom DO time-space variability through interplay of physical, heterotrophic, and autotrophic processes. Strong effects of pycnocline deepening may be particularly significant to this type of shallow coastal region with its sloping bathymetry, irregular topography, and pycnocline depth relative to the depth of the photic zone.

\section{METHODS}

Study region and relevant water column monitoring. This study examines data from 1992 to 1994 from intensive monitoring surrounding a future $2 \mathrm{~km}$ diffuser track of the outfall in western Massachusetts Bay
(Fig. 1). The study region is set within the mesoscale circulation of Massachusetts Bay (Geyer et al. 1992), but also receives substantial nutrient export from Boston Harbor to the west (Kelly 1997). Consequently, there is a decrease in surface water nutrients, turbidity, and chlorophyll from inshore to offshore across the 21 station sampling grid (e.g. Townsend et al. 1991; Kelly 1997). Depth-integrated primary productivity in this region is high $\left(-400\right.$ to $\left.600 \mathrm{gC} \mathrm{m}^{-2} \mathrm{yr}^{-1}\right)$ but fairly similar inshore to offshore during a given year (Kelly \& Doering 1997). From inshore to offshore across the sampling grid $(>10 \mathrm{~km})$, the bathymetry generally slopes from $\sim 20$ to $\sim 50 \mathrm{~m}$ water depth, but the bottom is both topographically irregular (Fig. 1) and heterogeneous in composition (Knebel 1993). A large portion of the area is non-depositional or erosional (hard sand or hard bottom [gravel, cobble]), especially most of the deeper eastern half of the area. Patches of soft-sediment, depositional areas are largely confined to the western portion of the field, at depths $\leq 30 \mathrm{~m}$; Fig. 1 (diamond symbols) shows the 3 principal sediment respiration stations of Giblin et al. (1995). Water respiration measurements at Stn N20P (Fig. 1) are given in this paper. Water quality trends with depth are discussed for a depth transect (Stns N12, N20P, N21, N16P, N06) through the middle of the sampling area (Fig. 1).

Water column sampling protocols and measurements for the Massachusetts Water Resources Management (MWRA) monitoring program followed common oceanographic methods (Albro et al. 1993). For each year, there were 14 to 16 surveys of the 21 station grid, approximately monthly during the cold season and about bi-weekly during summer and early fall. Data have been reported in the open literature and are fully available in detailed technical reports (see 'Acknowledgements'). The directed focus of this contribution is DO, associated physical, and metabolic parameters. Briefly, a CTD was downcast to a few meters above bottom. Temperature and conductivity were measured (SeaBird SBE-9, salinity then calculated); from these, density was calculated following Fofonoff \& Millard (1983). DO was measured in situ (SeaBird SBE-13). Sensor readings for DO were calibrated (post-survey) by Winkler titration (Oudot et al. 1988) using duplicate water samples carefully drawn from hydrocast bottles tripped at 5 depths on the upcast at a subset of stations, typically 6 for each 21 station survey ( $\mathrm{n}=30$ sets of duplicate DO determinations). Calibration regressions for each survey generally indicated strong agreement between the sensor and Winkler titrations within about $\pm 5 \%$ (i.e. regression slopes generally were between 0.95 and 1.05 when a zero-intercept was forced); only occasional outliers were found. When the water column was ther- 
Fig. 1. (a) The principal study area in western Massachusetts Bay, showing the sampling grid of 21 stations (labeled). The distance from Deer Island at the outer edge of northern Boston Harbor to the center of the grid near Stn N21 is $\sim 15 \mathrm{~km}$. A future submarine diffuser track (2 km long) will discharge effluent between Stns N20P and N16P. The station grid defines a square $\sim 10.5 \times 10.5 \mathrm{~km}$. Additional water column monitoring stations were inshore and offshore from this grid, but were sampled at a lesser frequency and were not a focus of this study. (b) Water column stations (4) relative to bathymetry (depths in $\mathrm{m}$ ). Bathymetry was provided by R. Signell (USGS, Woods Hole, MA, USA). The depth contour interval is $5 \mathrm{~m}$; shading is added at $30 \mathrm{~m}$ and then $40 \mathrm{~m}$ to indicate the general increase in depth from $\sim 20$ to $25 \mathrm{~m}$ to $-45 \mathrm{~m}$ from inshore (west-southwest) to offshore (east-northeast). The area has much bottom irregularity; hachures indicate upslope mounds ('drumlins', Knebel 1993)

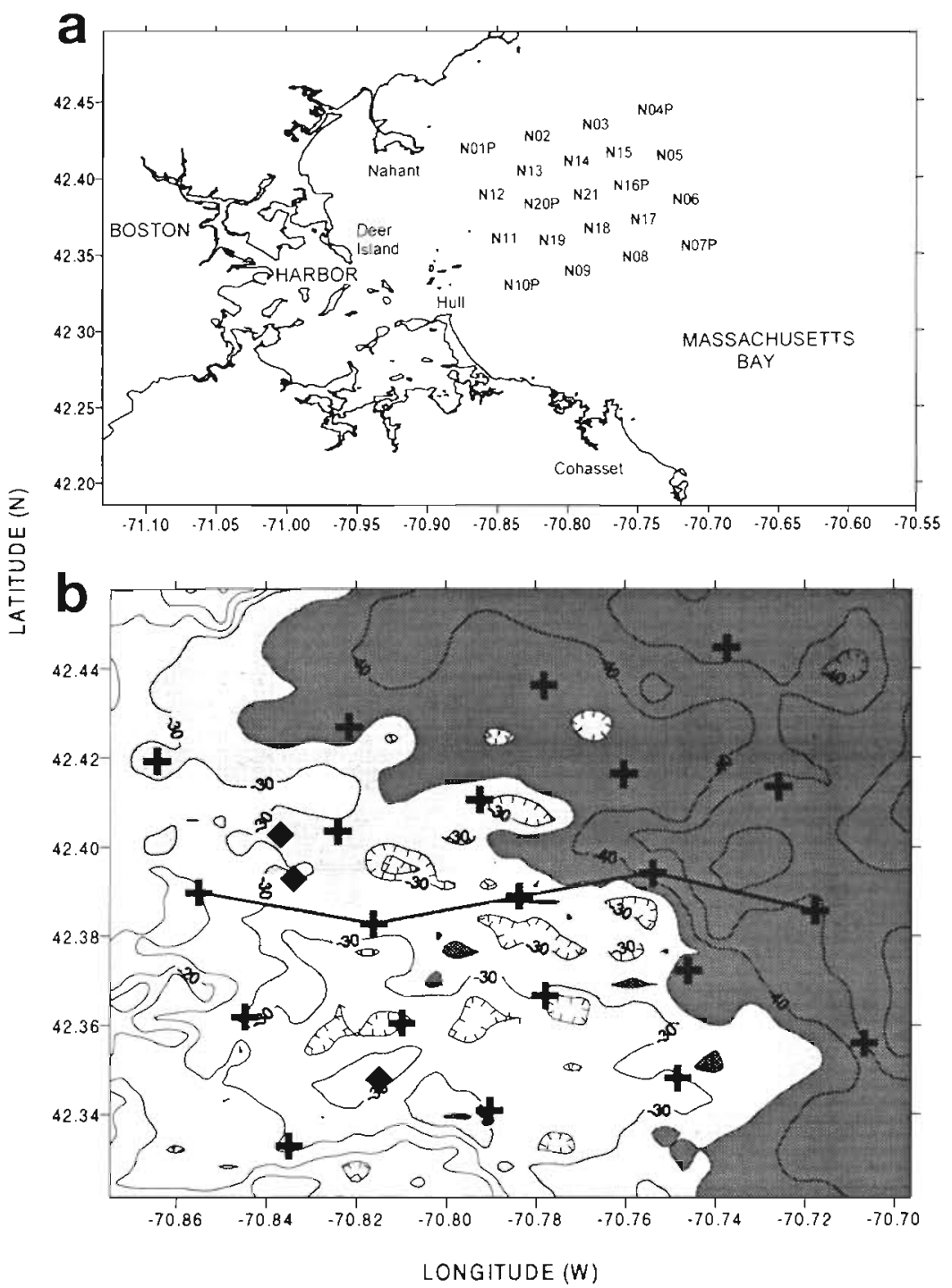

mally stratified we noted a lag in the response time of the DO sensor; accordingly, we believe the most reliable DO concentrations using the sensors were obtained on the upcast when the rosette was maintained for a short period ( $>0.5 \mathrm{~min}$ ) prior to hydrocast bottle firing. For this paper we report calibrated DO sensor data for each of the 5 depths of bottle firing at each sampling station. Water was drawn also from the upcast bottles for a variety of other measurements that are examined in this paper. For example, samples were used to determine chlorophyll a (in vitro extraction; Parsons et al. 1984), and chlorophyll results then were used to calibrate in situ fluorescence readings (Chelsea Aquatracker III, see Kelly 1997) post-survey, like DO. Kelly \& Doering (1997) detailed chlorophyll trends and measurements for net primary production (NPP) and their data are summarized for discussion in this paper. Additional water column respiration studies, as well as sediment respiration studies, are briefly described below because they form the empirical basis for metabolic functions used in modeling.

Modeling. Data manipulations, statistical analyses, and the modeling effort were performed with Quattro Pro (Borland 1993), SAS (1988), or Surfer (Golden 1994). We conducted modeling to predict DO changes in near-bottom water $\left(D O_{1}\right)$ during the stratified period when DO concentrations decline. The simple model, similar in basic concept and elements to previous efforts (e.g. Officer et al. 1984), assumed $D O_{t}$ is a function of an 'initial' bottom-water concentration $\left(D O_{i}\right)$ as strong thermal stratification is established, water column respiration $\left(R_{w c}\right)$, sediment respiration $\left(R_{\text {sed }}\right)$, and vertical flux $\left(F_{\mathrm{d}}\right)$ due to the concentration gradient between surface and bottom waters:

$$
D O_{t}=D O_{i}-R_{\mathrm{wc}}-R_{\mathrm{sed}}+F_{\mathrm{d}}
$$


Table 1 Description of model terms, derived functions, and data sources. Bold parameters use monitoring results directly as input to model

\begin{tabular}{|c|c|}
\hline \multicolumn{2}{|l|}{ Model } \\
\hline$\overline{D O_{t}}=$ & $D O_{i}-R_{\mathrm{wc}}-R_{\mathrm{sed}}+F_{\mathrm{d}}$ \\
\hline \multicolumn{2}{|r|}{ 为 } \\
\hline$\overline{D O_{t}}$ & $\begin{array}{l}\text { DO in } \mathrm{mg} \mathrm{l}^{-1} \text { predicted in near-bottom water, } t= \\
\text { time in days from June survey }\end{array}$ \\
\hline$D O_{i}$ & $\begin{array}{l}\text { DO in } \mathrm{mg} \mathrm{l}^{-1} \text { measured in near-bottom water, } i= \\
\text { mean for June survey }\end{array}$ \\
\hline$R_{\mathrm{wc}}$ & Respiration in the water column, in $\mathrm{mg} \mathrm{I}^{-1} \mathrm{~d}^{-1}$ \\
\hline$R_{\text {sed }}$ & $\begin{array}{l}\text { Respiration in depositional sediments, as } \mathrm{mg} \\
\mathrm{m}^{-2} \mathrm{~d}^{-1}\end{array}$ \\
\hline$F_{\mathrm{d}}$ & $\begin{array}{l}\text { Vertical, diffusive flux of } \mathrm{DO} \text { between surface } \\
\text { and bottom layers, as } \mathrm{mg} \mathrm{m} \mathrm{m}^{-2} \mathrm{~d}^{-1}\end{array}$ \\
\hline \multicolumn{2}{|c|}{ further defined as } \\
\hline \multicolumn{2}{|c|}{$\begin{array}{l}R_{w c}=\text { Normalized respiration } \times \boldsymbol{F l u} \text { (Normalized respira- } \\
\text { tion from Eq. 3, see text) }\end{array}$} \\
\hline \multicolumn{2}{|c|}{$\begin{array}{l}1994 R_{\text {sed }}=0.190+(0.040 \times T)_{i} \text { multiplied by } f \text { and divided } \\
\text { by } B L \text { gives volumetric rate for whole study area, } \mathrm{mg} \mathrm{l}^{-1} \\
\mathrm{~d}^{-1} \text { (from Giblin et al. } 1995 \text { data) }\end{array}$} \\
\hline \multicolumn{2}{|c|}{$\begin{array}{l}1993 R_{\text {sed }}=0.216+(0.044 \times T)_{i} \text { multiplied by } f \text { and divided } \\
\text { by } B L \text { gives volumetric rate for whole study area, } \mathrm{mg} \mathrm{l}^{-1} \\
\mathrm{~d}^{-1} \text { (from Giblin et al. } 1994 \text { data) }\end{array}$} \\
\hline \multicolumn{2}{|c|}{$\begin{array}{l}F_{\mathrm{d}}=k \times\left(D O_{\text {suri }}-D O_{t}\right) / h_{i} \text { divided by } B L \text { gives volumetric } \\
\text { rate, } \operatorname{mg~l}^{-1} \mathrm{~d}^{-1} \text { (after Okubo 1971) }\end{array}$} \\
\hline \multicolumn{2}{|c|}{ using following parameters } \\
\hline$T$ & $\begin{array}{l}\text { Temperature, near-bottom average for each sur- } \\
\text { vey; coefficient in } R_{\mathrm{wc}} \text { and } R_{\text {sed }}\end{array}$ \\
\hline Flu & $\begin{array}{l}\text { In situ fluorescence, near-bottom average for } \\
\text { each survey; used to calculate } R_{\mathrm{wc}}\end{array}$ \\
\hline$f$ & $\begin{array}{l}\text { Factor to extrapolate to whole study area from } \\
\text { rates in depositional sediments (see text) }\end{array}$ \\
\hline$k$ & $\begin{array}{l}\text { Eddy-diffusion coefficient, standard uses } 0.1 \mathrm{~cm}^{2} \\
\mathrm{~s}^{-1} \text { (R. Geyer pers. comm) }\end{array}$ \\
\hline$h$ & $\begin{array}{l}\text { Thickness of pycnocline; fixed assumes } 10 \mathrm{~m} \text {, } \\
\text { variable layering based on observations ( } h \text { ranges } \\
\text { from } 12 \text { to } 21 \mathrm{~m} \text {; refer also to summary of Fig. } 10 \text { ) }\end{array}$ \\
\hline$B L$ & $\begin{array}{l}\text { Thickness of bottom water layer; fixed assumes } \\
15 \mathrm{~m} \text {, variable layering based on observations } \\
\text { (BL ranges from } 19 \text { to } 4 \mathrm{~m} \text {; refer also to summary } \\
\text { of Fig. 10) }\end{array}$ \\
\hline$D O_{\text {suri }}$ & $\begin{array}{l}\text { DO in } \mathrm{mg}^{-1} \text { at bottom of surface mixed layer, } \\
\text { mean for each survey }\end{array}$ \\
\hline
\end{tabular}

Model terms are defined in Table 1. Data input to the model came from the monitoring measurements (see Table $1 ;$ e.g. T, Flu, DO surf, and $D O_{\text {, were mea- }}$ sured and $h$ and $B L$ were estimated from vertical density profiles). Input data were available for $D O_{1}$ and the sequence of surveys (about bi-weekly) provided data to calculate the 3 other terms (see derivations given below). We used simple time-weighted averaging of predicted rates $\left(R_{\mathrm{wc}}, R_{\mathrm{sed}}\right.$, and $\left.F_{\mathrm{d}}\right)$ between surveys (multiplied by the interval [days] between surveys to calculate concentrations) to calcu- late $D O$, corresponding to each survey. Model predictions were compared to observed DO concentrations from the monitoring program and covered the period from the June starting condition to the survey where the annual mean DO minima was measured (September or October, depending on the year). Additional potential model terms - biological production and horizontal advection - are considered in the discussion.

Water column respiration $\left(\boldsymbol{R}_{w c}\right)$. Studies were conducted at Stn N20P during strong stratification (June to October 1994). Briefly, a series of dark $300 \mathrm{ml}$ BOD bottles (acid-cleaned) were carefully filled from hydrocast bottles. Initial samples were fixed immediately; others were maintained at constant temperature near the collection temperature and subsequently fixed at time intervals up to $2 \mathrm{~d}$, and in some cases to 7 d. For each time period, duplicate or triplicate bottles were titrated by Winkler titration (Oudot et al. 1988). The slope of a linear regression of DO concentration on time estimates the rate of water respiration per unit volume (mg DO $\mathrm{l}^{-1} \mathrm{~d}^{-1}$ ). Sampling was conducted at 3 depths in June, August, and October. The deepest sampling was in the upper subpycnocline; we intended to exclude the influence of resuspended material. In retrospect, depth trends indicated that samples should have been taken deeper. The majority of total water column respiration occurred in the upper $15 \mathrm{~m}$ of the water column; rates were a function of organic matter concentration (indicated by either particulate organic carbon or fluorescence) and temperature $(T)$ and also generally decrease exponentially, rather than linearly, with the depth $(Z)$ of collection (Kelly \& Doering 1995). Subsequently we projected rates to average near-bottom conditions, as follows.

We first 'normalized' measured volumetric respiration rates by dividing by in situ fluorescence ( $F l u$, see Table 1). Fluorescence was the indicator of organic matter which was measured on all surveys and was thus to provide an input on field conditions to the respiration function (see more below). Acknowledging an observed exponential decline of respiration with depth, a stepwise multiple regression analysis was then performed using the natural $\log (\ln )$ of normalized respiration $\left[\mathrm{mg}\right.$ DO $(\mu \mathrm{g} F \mathrm{Flu})^{-1} \mathrm{~d}^{-1}$ ] as the dependent variable, with $Z$ and $T$ as independent variables. Although data were limited (Table 2), a significant regression was obtained $\left(\mathrm{R}^{2}=0.73, \mathrm{df}=6\right)$ and the result expressed in exponential form was:

Normalized respiration $=0.0446\left(\mathrm{e}^{-0.032 z}\right)\left(\mathrm{e}^{0.053 r}\right)$

Near-bottom measurements of DO across the sampling grid were made at an average $Z$ of $-34 \mathrm{~m}$ in early fall 1994. Substituting $Z=34$ into Eq. (2) yields a sim- 
Table 2. Water column respiration rates (Stn N20P, 1994) used as a basis for establishing $R_{\mathrm{wc}}$ in the DO decline model. All data from Kelly \& Doering (1995)

\begin{tabular}{|lccccc|}
\hline Month & $\begin{array}{c}\text { Depth } \\
(\mathrm{m})\end{array}$ & $\begin{array}{c}\text { Incubation } T \\
\left({ }^{\circ} \mathrm{C}\right)\end{array}$ & $\begin{array}{c}\text { In situ Flu } \\
\left(\mu \mathrm{K} \mathrm{I}^{-1}\right)\end{array}$ & $\begin{array}{c}\text { Measured dark respiration } \\
\left(\mathrm{mg} \mathrm{O}_{2} \mathrm{I}^{-1} \mathrm{~d}^{-1}\right)\end{array}$ & $\begin{array}{c}\text { Normalized dark respiration } \\
{\left[\mathrm{mg} \mathrm{O}_{2}\left(\mu \mathrm{O} \mathrm{Flu}^{-1} \mathrm{~d}^{-1}\right]\right.}\end{array}$ \\
\hline June & 1.6 & 16.5 & 4.16 & 0.46 & 0.11 \\
June & 9.0 & 7.0 & 1.99 & 0.12 & 0.06 \\
June & 17.7 & 7.0 & 3.27 & 0.10 & 0.03 \\
August & 2.6 & 16.8 & 1.33 & 0.16 & 0.12 \\
August & 14.3 & 13.5 & 2.35 & 0.17 & 0.07 \\
August & 21.0 & 12.5 & 1.39 & 0.07 & 0.05 \\
October & 1.9 & 14.5 & 3.28 & 0.21 & 0.07 \\
October & 13.3 & 14.5 & 5.45 & 0.24 & 0.04 \\
October & 21.3 & 12.0 & 1.30 & 0.05 & 0.04 \\
\hline
\end{tabular}

pler form with predicted rates related to water temperature:

$$
\text { Normalized respiration }=0.015 \mathrm{e}^{0.053 \mathrm{~T}}
$$

The equation yields a $Q_{10}\left(5\right.$ to $\left.15^{\circ} \mathrm{C}\right)$ of 1.7 . Considering uncertainty in the exponent for the $T$ coefficient (mean \pm standard error $=0.053 \pm 0.031)$, this value is close to a conventional value of 2 . For the model (Table 1), $R_{\mathrm{wc}}$ was calculated for each survey by multiplying the result of Eq. (3) (normalized respiration) times the average near-bottom Flu measured for that survey (cf. Table 2), thus converting rates again to $\mathrm{mg}$ DO $\mathrm{l}^{-1} \mathrm{~d}^{-1}$. Sensitivity to variations in Eq. (3) coefficients is examined in results.

Sediment respiration $\left(\boldsymbol{R}_{\text {sed }}\right)$. Giblin et al. $(1994,1995)$ measured sediment respiration on intact cores taken from 3 sites $(\sim 33$ to $35 \mathrm{~m})$ in the only sizable patches of depositional sediment (silt-clay/sandy-silt) within the 21 station grid where suitable box cores reliably could be obtained (Fig. 1). Five sets of measurements were made for the period of March to October in both 1993 and 1994. Sediment oxygen uptake rates generally increased with temperature, with rates at $-7^{\circ} \mathrm{C}$ (July) near $400 \mathrm{mg} \mathrm{O}_{2} \mathrm{~m}^{-2} \mathrm{~d}^{-1}$ and rates at $>9^{\circ} \mathrm{C}$ (August and October) near $675 \mathrm{mg} \mathrm{O}_{2} \mathrm{~m}^{-2} \mathrm{~d}^{-1}\left(\mathrm{Q}_{10}\left[5\right.\right.$ to $\left.\left.15^{\circ} \mathrm{C}\right] \sim 2\right)$, and were adequately expressed as a linear function of temperature. However, there were differences in rates between the 2 years that were independent of temperature. Sediment respiration in August and October 1993 was $>10 \%$ higher than August and October 1994 (paired $t$-test, $\mathrm{p}=0.02, \mathrm{n}=6$ ) even though bottom water temperatures were $\geq 4^{\circ} \mathrm{C}$ higher in 1994 (Table 3). Therefore, separate linear predictive regressions were used to calculate $R_{\text {sed }}$ from $T$ in 1994 and 1993 (Table 1).

Two modifiers to $R_{\text {sed }}$ were needed to include the term in the overall model (Eq. 1). Sediment respiration is measured on an areal basis ( $\mathrm{mg} \mathrm{DO} \mathrm{m} \mathrm{m}^{-2} \mathrm{~d}^{-1}$ ); dividing $R_{\text {sed }}$ by $B L$ (and then converting from $\mathrm{m}^{-3}$ to $\mathrm{l}^{-1}$ ) provides a volume-based rate compatible with $R_{\mathrm{wc}}$ and the concentration term, $D O_{i}$ (see Table 1). $R_{\text {sed }}$ has to be additionally adjusted by a factor $f$ (Table 1) to account for bottom-type variation throughout the study area. From Knebel (1993) we roughly estimated the study area is about $29 \%$ depositional sediments, the remainder being sandy or hard bottom (gravel, boulder). Most of the depositional bottom is biased to the shallower western side of the field where sediment flux measurements were possible (Fig. 1). There is little literature to go on, but based on rates from sand versus mud sites in Boston Harbor (Giblin et al. 1997. Nowicki et al. 1997) and from our own experimental studies on metabolism of freshly settled organic matter (Kelly \& Nixon 1984, Doering 1989), we first assumed that respiration rates from non-depositional areas were about $20 \%$ of depositional site rates. To extrapolate $R_{\text {sed }}$ for the entire study area from measurements in depositional areas, $f$ was then calculated by weighting relative rates by relative area $(f=[1.0 \times 0.29]+[0.2 \times 0.71]=0.43)$. A lower $f$ would be more applicable to the deeper, cooler, less depositional fraction of the study area (eastern side) and, depending on the local scale in the study region, different $f$ values might be appropriate. Model sensitivity results below examine the influence of lowering $f$ to 0.3 ( = a condition where $23 \%$ of area is depositional, and non-depositional sediment rates $=10 \%$ of depositional-sediment measurements).

Vertical diffusion $\left(F_{\mathrm{d}}\right)$. Diffusion was modeled after Okubo (1971) as a function of an eddy-diffusion coefficient ( $k$ ) and the DO concentration gradient between the surface and subpycnocline layers, calculated as the concentration difference divided by the thickness of the pycnocline $(h)$ (Table 1 ). The formulation expresses the rate (generally into the bottom layer because $D O_{\text {surf }}$ $\geq D O_{t}$ ) of DO diffusion as a cross-sectional area; as for $R_{\text {sed, }}$, the term must be modified by the thickness, $B L$, of the bottom-water layer into which it is added, to convert to a volumetric rate $\left(\mathrm{mg} \mathrm{l}^{-1} \mathrm{~d}^{-1}\right)$ consistent with other terms of the model. Based on studies by R. Geyer 


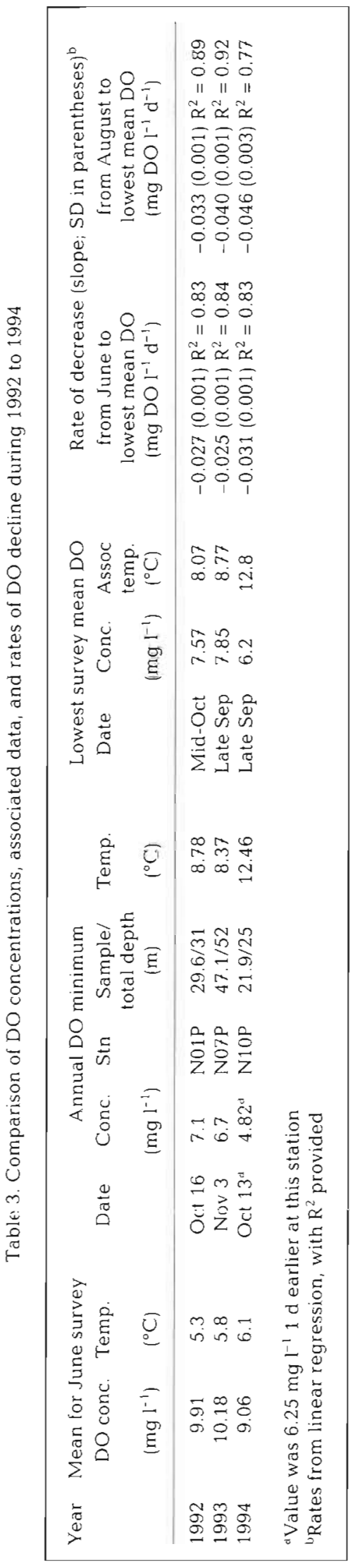

(WHOI, pers. comm.), a nominal standard for $k$ of $0.1 \mathrm{~cm}^{2} \mathrm{~s}^{-1}$ was used. The value of $k$ during strong summer stratification may be even lower than 0.1 (and thus exert a smaller influence on the resultant predicted DO than suggested by modeling), but for sensitivity analyses, the effect of doubling $k$ (increasing the transfer rate) is included in results.

\section{RESULTS}

\section{Monitoring}

Annual cycle of $D O$

Time and depth patterns of $D O$, temperature, and density are shown for an example station in 1994 (Fig. 2). Briefly, a number of generalizations hold for most stations and across sampling years:

(1) DO (concentration, $\mathrm{mg} \mathrm{l}^{-1}$, and \% saturation) was generally highest in winter-spring during the coldest temperatures of the year.

(2) Near-surface DO values were consistently $\geq$ nearbottom DO values; surface and bottom layer DO values began to diverge with initiation of spring stratification ( Day 90 to $120, \sim$ April)

(3) Thermal layering was well expressed by early summer (e.g. Day 171, June) and the pycnocline at this time was in the upper water column.

(4) Through mid-summer ( Day 220, early August) DO levels in the surface 15 to $20 \mathrm{~m}$ (often within the pycnocline) remained high, $>9 \mathrm{mg} \mathrm{l}^{-1}$ and $\geq 100 \%$ saturation.

(5) Bottom-water DO concentrations progressively decreased to reach the annual DO minima in early autumn ( Day 270 to 300 , late September to early November) when the shallow summer surface layer and its underlying pcynocline (also thermocline) had deepened, leaving only a thin near-bottom layer with the lowest DO and highest temperature attained for the year.

(6) As the entire water column cooled and mixed ( Day 310, November), DO levels again became similar top to bottom.

(7) During each season, higher DO values land $>100 \%$ saturation) usually coincided with high chlorophyll concentrations (Fig. 2). For example, high DO concentrations occurred throughout the water column in association with an extended spring chlorophyll bloom as seasonal stratification began ( Day 60 to 120 , late February through April, Fig. 2). Although more constrained to the surface layer, summertime DO concentrations were also high during periods of elevated photic zone chlorophyll concentrations $\left(>2.5 \mu \mathrm{g} \mathrm{l}^{-1}\right)$. Near-surface DO levels were briefly elevated during a 
fall diatom bloom ( Day 270 to 300 , September to November).

\section{Inter-annual comparison for DO}

Annual cycles of DO for the period 1992 to 1994 show some seasonal regularity as a consequence of thermal stratification (Fig 3) However, inter-annual differences in the tuming and level of DO minimum achieved for the whole field (and individual stations) was apparent (Figs. 3 \& 4). Most notably, 1994 stood out as different from 1992 and 1993, particularly with respect to bottom water DO minima (Fig. 4, Table 3). Overall similarities and differences are summarized as follows:

(1) The lowest survey mean DO $16.2 \mathrm{mg} \mathrm{l}^{-1}$ for $\mathrm{n}=21$ stations) was observed in 1994. For 1993 and 1992, survey minima were 7.85 and 7.57 $\mathrm{mg}^{-1}$ respectively, both much higher than 1994 (Table 3).

(2) The timing of the annual survey minimum ranged from late September to mid October. The lowest individual readings for each year were found later, between mid October and early November, and at different stations within the region (Table 3). Differences in annual survey minima among years were not a simple result of stratification lasting later into the fall, as the minima for 1994 occurred about the same time as other years (late September). Although mid October 1992 had the survey minıma DO for that year, note that no survey was conducted in late September 1992 ( Day 275).

(3) DO varied substantially across years at the beginning of strong stratification in June (Table 3), when a divergence between surface and bottom water DO concentrations became evldent. DO in bottom waters in June 1994 was $\sim 1 \mathrm{mg} \mathrm{l}^{-1}$ lower than June of other years (Fig. 4).

(4) A broad range of bottom-water DO concentrations were observed in fall when a portion of the sampling field had mixed, yet deeper water was still stratified.

Fig. 2. Temperature, density, DO (concentration, \% saturation), and fluorescence (as chl a) during 1994 at Stn N21 in the center of sampling area Contouring is based on sampling at 5 depths (indicated) for 16 surveys from late February to early December. For reference the June survey was Day 171, the late August survey was Day 238, and the mid October survey was Day 284
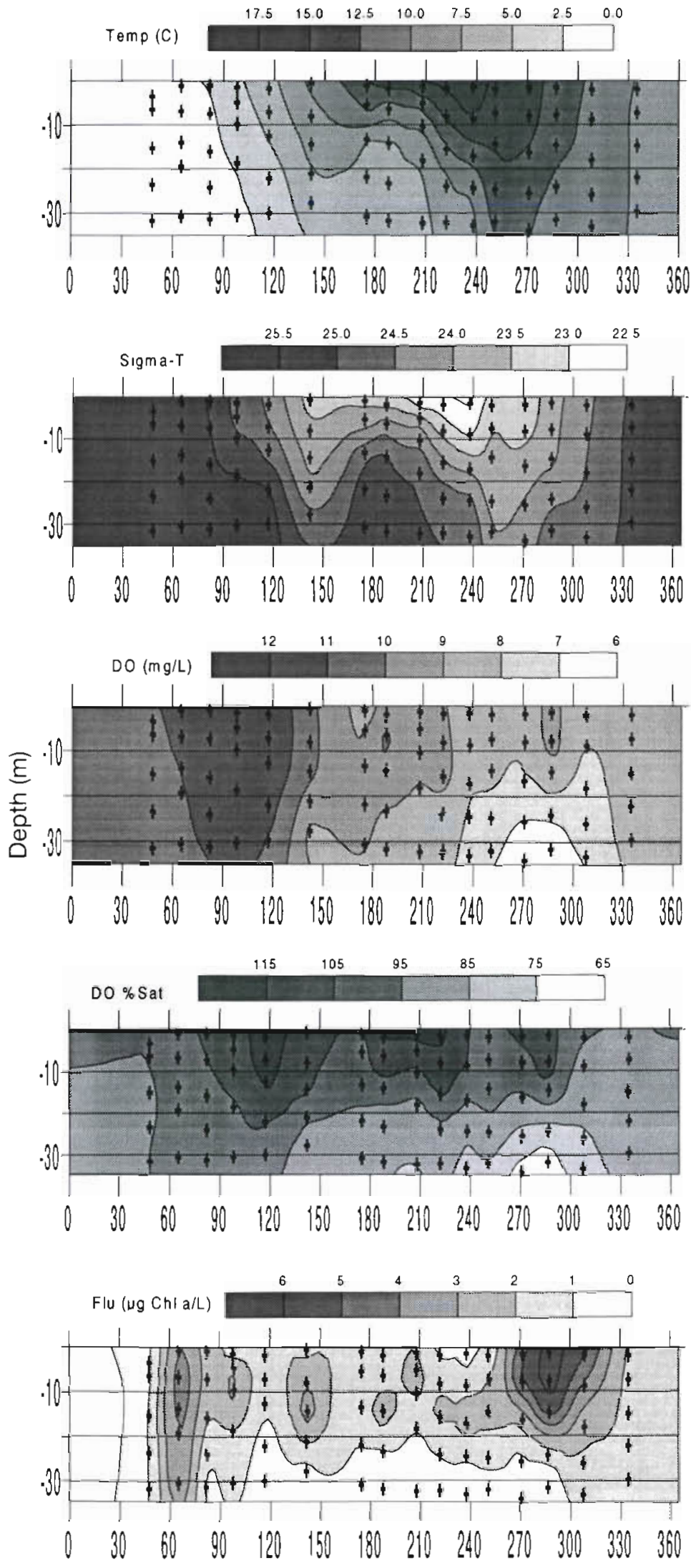

Day of Year 

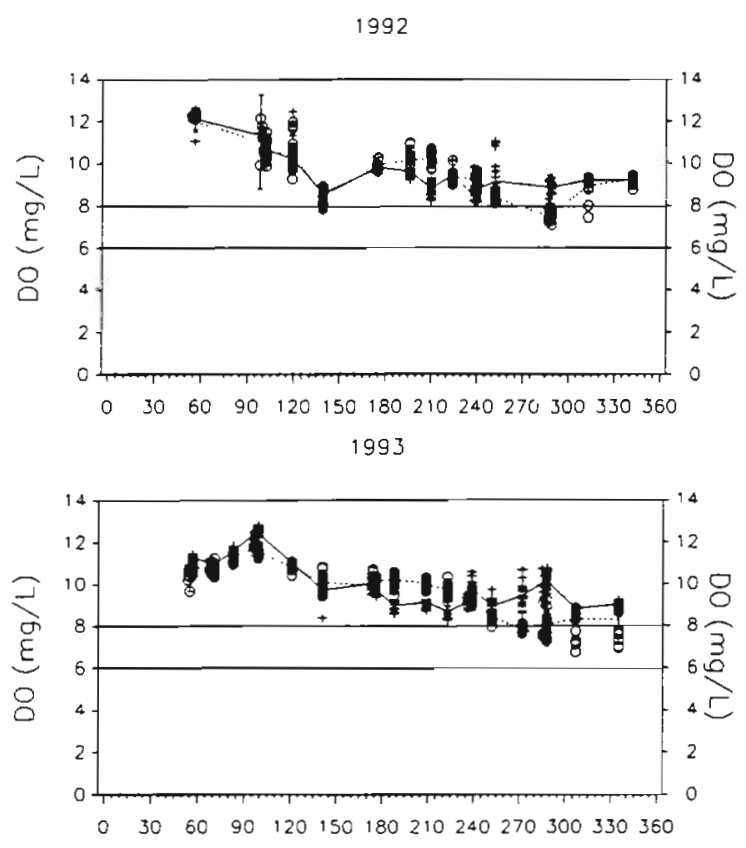

1994

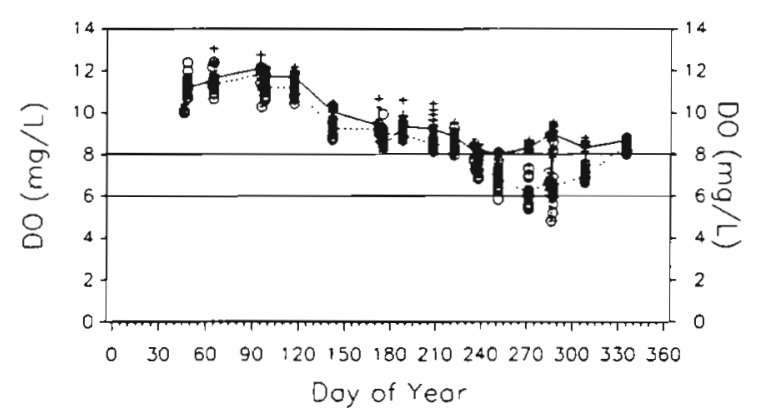

Fig. 3. DO (concentration) over 3 consecutive annual cycles. Solid lines and plus (+) symbols show mean and individual values $(\mathrm{n}=21)$ for surface water at each survey. Dotted lines and circles shown mean and individual values $(n=21)$ for near-bottom water at each survey. Vertical lines with bars (often obscured by points) show \pm standard error of the mean at survey

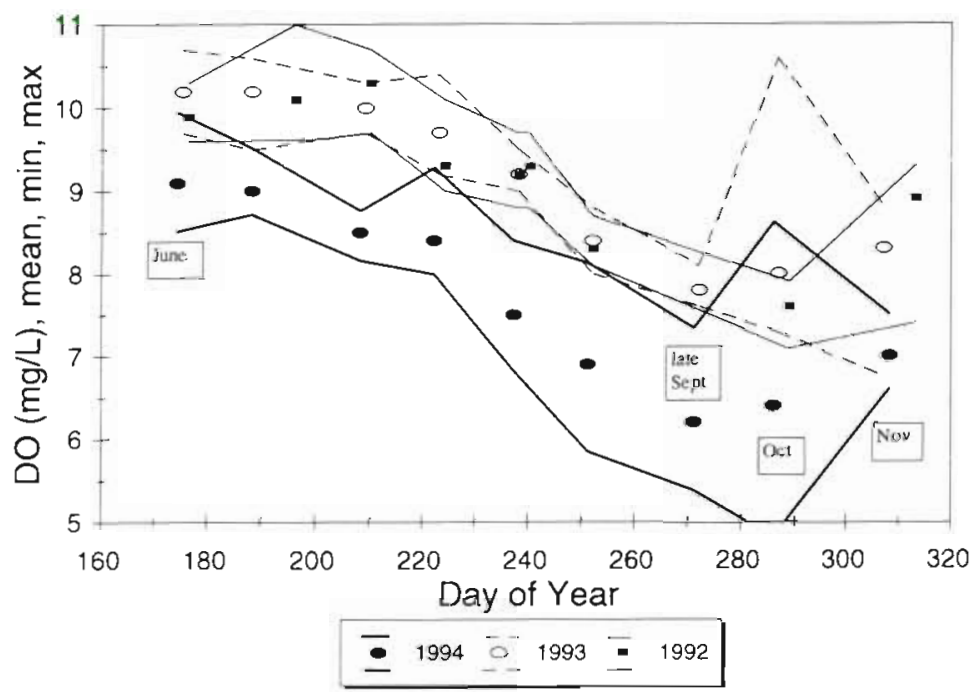

Seasonal decline of DO in bottom waters: comparative rates and trends

The 3 annual cycles showed differences with respect to subpycnocline DO, including: (1) 'starting' concentrations (early in summer), (2) minima achieved, (3) the range of DO concentrations across the field within a survey, and (4) the rates of decline during stratification. For example, in early summer 1992, there was a rise in bottom-water DO in early summer before concentrations began their continuous decline. In contrast, 1994 generally had low DO concentrations from June to late September/mid-October (Fig. 4). For all years, the broadest range of values within a survey occurred during or after the point where the survey-mean minima occurred, i.e. late September $(1993,1994)$ or October (1992). The broad ranges coincided with water column mixing of only a portion (not all) of the sampling field. Minimum individual DO readings were noted at the survey after the lowest survey mean was detected in 1993 (i.e. November) and 1994 (i.e. October) (cf. Table 3); these individual measurements were made where a pycnocline was still evident in the water column.

Bottom-water DO concentrations were regressed on time (days), where data were constrained only to the period of strong stratification from June to the survey with lowest mean DO in each year (September or October). All regressions were highly significant $(\mathrm{p}>F=$ 0.0001 ) and (negative) slopes (Table 3) estimate the rate of DO decline. Declines ranged from 0.025 to $0.031 \mathrm{mg}$ DO $\mathrm{l}^{-1} \mathrm{~d}^{-1}$. The second half of each year's stratification period had a faster DO decline than the first, suggesting a non-linear decline. Using data from early August to the minimum survey DO in each year gave rates of decline up to -20 to $50 \%$ faster than estimated for the entire period (Table 3). The fastest late-season decline was estimated for 1994 data $\left(0.046 \mathrm{mg} \mathrm{l}^{-1} \mathrm{~d}^{-1}\right)$. In comparison, the decline for the early season (June to early August 1994) was $0.015 \mathrm{mg} \mathrm{l}^{-1} \mathrm{~d}^{-1}$ and the average decline for the whole period was $0.031 \mathrm{mg}$ $\mathrm{l}^{-1} \mathrm{~d}^{-1}$ (Table 3).

Variability late in the stratified season

Bottom water quality varied greatly in early Autumn at almost every scale of observation. Description of some spatial-temporal patterns in 1994 help frame later discussion.

Fig. 4. Comparison of DO decrease in bottom water during stratified seasons 1992 to 1994 . Mean and range (minimum, maximum) of concentrations are plotted by survey 
On September 28, 1994, the surveyaveraged DO minima for the year was observed (Table 3 ) and values $<6 \mathrm{mg} \mathrm{l}^{-1}$ were common, but a patchy distribution was evident. One station (N19) at the edge of a large drumlin (bathymetric high, less than $25 \mathrm{~m}$ deep; Fig. 1) had a higher concentration (>7 $\mathrm{mg} \mathrm{l}^{-1}$ ), a feature which interrupted the general pattern of values $<6 \mathrm{mg} \mathrm{l}^{-1}$ for a central block of stations (not shown). About $2 \mathrm{wk}$ later, on October 14, DO concentrations for most of the shallower $(-25$ to $35 \mathrm{~m})$ central portion of the region had risen and were above $6.5 \mathrm{mg} \mathrm{l}^{-1}$ (cf. Fig. 5). Stations near bathymetric highs (N12 and N18) again stood out for high readings (>8 mg/) (not shown). In contrast, Stn N01P in the northwestern corner of the sampling field is at the head of a trough of deeper water extending offshore; this corner of the field had low DO and this station in particular had a reading $<5.5 \mathrm{mg} \mathrm{l}^{-1}$. These and other observations suggest influence of the irregular bathymetry in the study area upon DO, and this influence is expressed as shallower areas begin to mix to the bottom slightly earlier in the fall.

A transect (Fig. 5) depicts the general relationship among sloping bathymetry, water column structure, and DO concentrations. This transect represents a corridor of generally increasing depth that cuts through the middle of the study region between several topographic mounds. Comparing patterns across this transect from September to November 1994 (only October shown, Fig. 5), the following results were noted:

(1) The pycnocline generally deepened and thinned. In late September, a 10 to $15 \mathrm{~m}$ thick pycnocline intersected the bottom at shallower stations $(\leq 30 \mathrm{~m})$. By November, a $<10 \mathrm{~m}$ thick pycnocline intersected the bottom near -34 to $40 \mathrm{~m}$ depth. Between September and November, the inshore half of the transect became mixed.

(2) Near-bottom temperature reached an annual maximum for most of the field in late September (cf. Table 3, Fig. 2). A gradual progression of cooler water upslope across the field occurred from September to November. There was an accompanying progression of slightly more saline (e.g. $>32.2$ PSU) bottom water upslope as the pycnocline deepened and the field destratified from inshore to offshore. By
October 14,1994
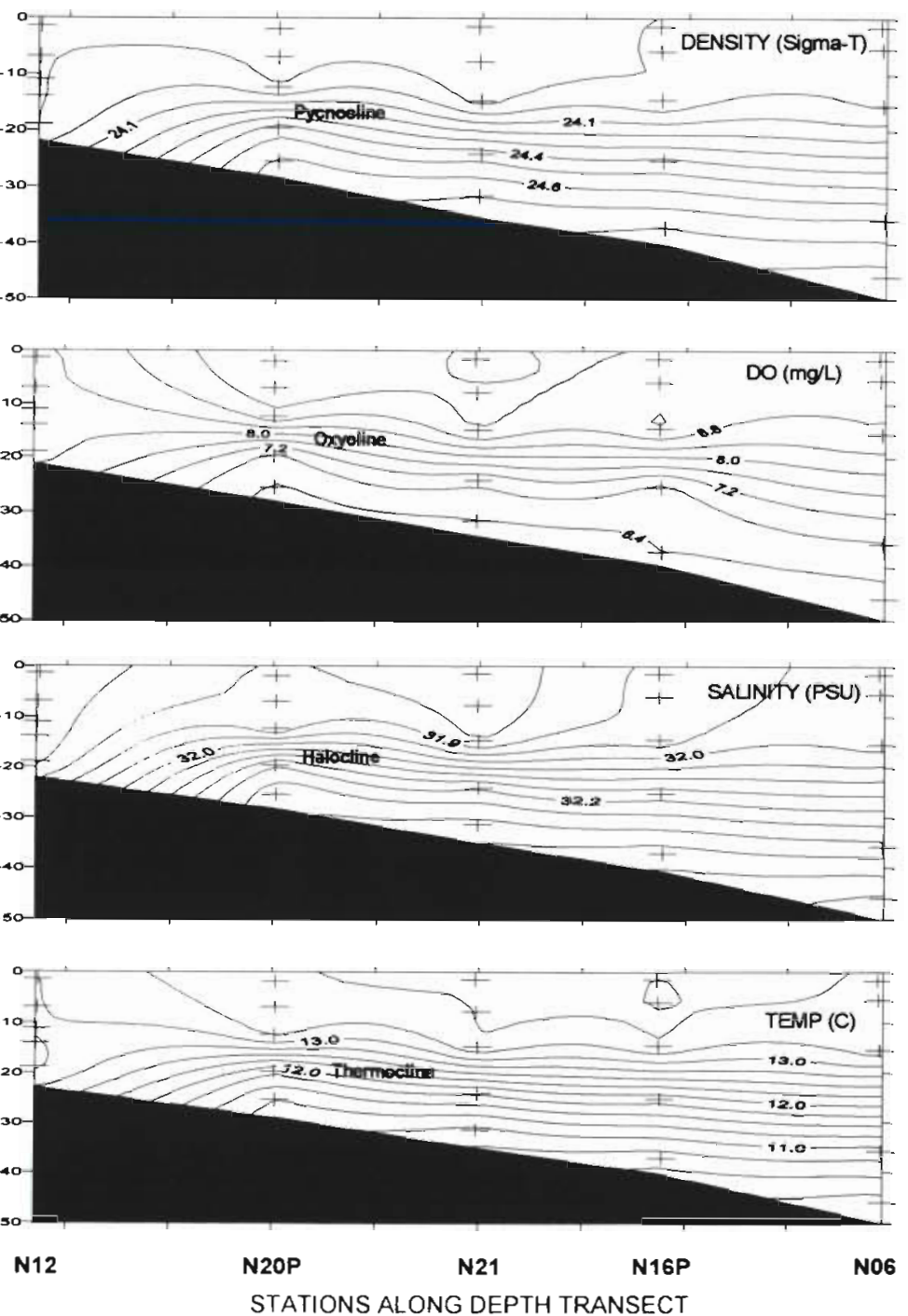

STATIONS ALONG DEPTH TRANSECT

Fig. 5. Contoured trends in parameters over a transect from shallow to deep stations across the study area (cf. Fig. 1)

November, a weak pycnocline/halocline persisted only at the deepest stations.

(3) Field-wide average minima in DO $\left(<6 \mathrm{mg} \mathrm{l}^{-1}\right)$ and maxima in temperature were observed coincidently at a time when the entire study area was within or below the pcynocline.

(4) There was a sharp oxycline, usually associated with the pycnocline. Lowest DO levels were usually measured at the thin leading edge of the subpycnocline layer, downslope of the location where the pycnocline intersected the bottom (typified in Fig. 5).

Other years had generally similar progressions to 1994. For the 5 station transect, the survey having the lowest mean DO for each year (i.e. October 16, 1992, September 29, 1993, September 28, 1994) represented 
a condition when the pycnocline was at or near the bottom at the shallowest station and the rest of the field was a fully stratified, 2-layer system with a relatively thin bottom layer. Consistently, low DO was found near the leading edge of the pycnocline.

\section{Model results and sensitivity analysis}

\section{DO decline model}

With $R_{\text {wc }}$ and $R_{\text {sed }}$ terms established by equations, the observed input values or $T$ and Flu for 1994, and standard assumptions of $k=0.1$ and $f=0.43$, DO model predictions under the assumption of a constant water column structure (i.e. 'fixed' layering) approximated the observed decline of mean concentrations measured across the sampling grid from June to October (Fig. 6a). However, in this 'fixed layering' case, the rate of DO decline increased only very slightly through the period and the model did not capture the late season (August to September) increase in DO decline that was apparent in the data. Since the physical structure did vary in the observation data set (e.g. Figs. $2 \& 5$ ) and $f$ has uncertainty, we explored effects of varying $k, h, B L$, and $f$ of the model while holding others constant for each prediction.

Neither the temporal trend nor extent of DO decline varied substantially when $k$ was doubled from 0.1 to $0.2 \mathrm{~cm}^{2} \mathrm{~s}^{-1}$. Everything else being held constant, the resultant DO predicted minima at Day 270 with a doubling of $k$ generally differed by $<0.2 \mathrm{mg} \mathrm{l}^{-1}$ (not shown in graphs). Variations in $k$ had a small effect on overall results, in part, because because $h$ was relatively broad $(\geq 10 \mathrm{~m})$. With a less diffuse pycnocline (smaller $h$ ) the relative effect of $k$ and diffusive input of DO would increase, but the magnitude of diffusive expression on DO still also depends on $B L$.

In contrast, variations in parameters of water column layering (i.e. especially $B L$, but including $h$ ) had substantial effects on results. The pycnocline generally broadened ( $h$ increased) and deepened ( $B L$ decreased) (e.g. Fig. 2) over the summer, so a 'variable layering' condition was modeled using average observations for $B L$ and $h$ at each survey. Comparison of model results of fixed versus variable layering (Fig. 6a) suggests that seasonal changes (especially deepening) of the pycnocline can produce lowered DO. Even with no change in temperature or the metabolic functions, lowered DO can be attained because a decrease in $B L$ yields a smaller volume of water on which $R_{\text {sed }}$ is expressed. Varying $B L$ and $h$ concurrently affects $F_{d}$; however, the increases in $h$ over the period modeled pretty much of fset the effect of decreased $B L$ (with respect to the $F_{\mathrm{d}}$ term) and moreover, as suggested above, contribution of the $F_{\mathrm{d}}$ term was generally minor compared to metabolic terms. Compared to fixed layering, the observed deepening of the pycnocline in 1994 and resultant 'thinning' of the near-bottom subpycnocline layer (smaller $B L$ ) was especially effective at increasing DO decline rates towards the end of the period. Consequently, for the variable layering case, predicted DO concentrations late in stratification were near the minimum values observed within the sampling area (Fig. 6a).

Comparison of assumptions on $f$ illustrates another effect (Fig. 6b). Use of a lower $f(=0.30 \mathrm{vs}$ the 'standard' $0.43)$ produced a result that more strongly followed the mean observed DO trend for almost the entire period a

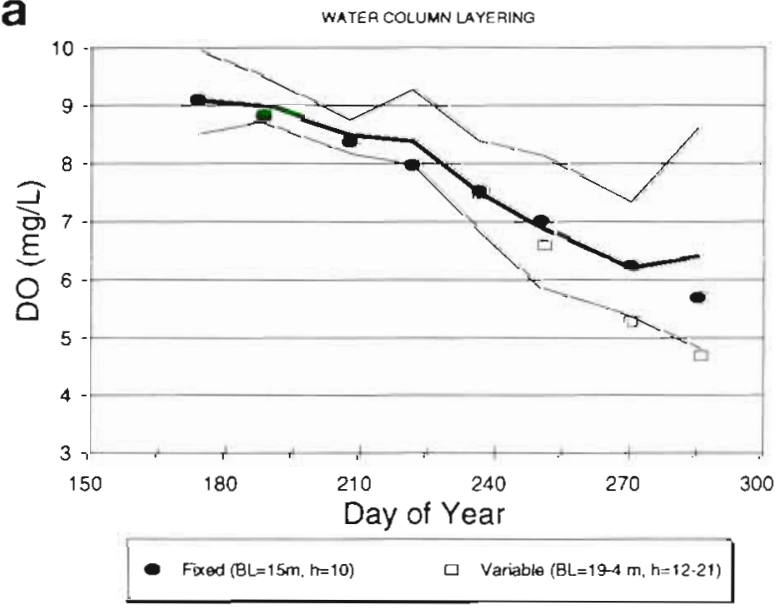

b

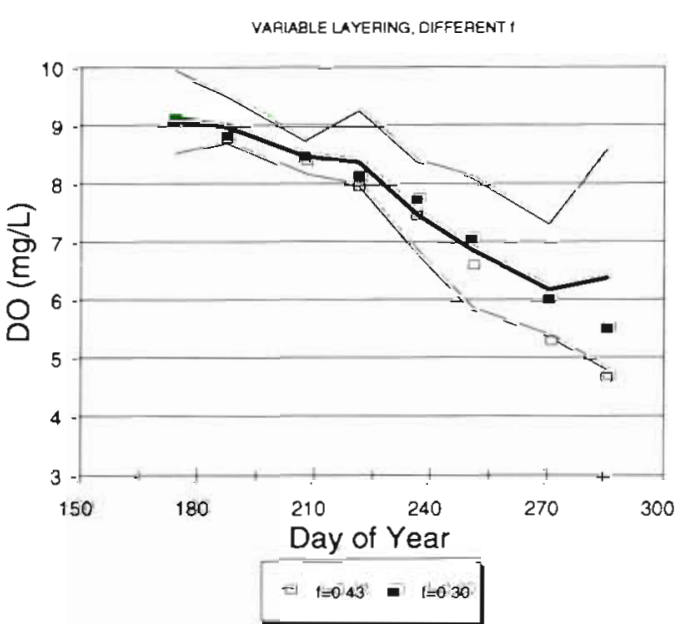

Fig. 6. DO decline model results versus observed DO concentrations (mean, minimum, and maximum indicated by lines) in 1994 (a) Comparison of observed data with model results using different water column layering assumptions (see text). (b) Comparison of observed data with model results using different assumptions for sediment respiration extrapolation $f$. Note that the $f=0.43$ case is the same result as shown in (a) 


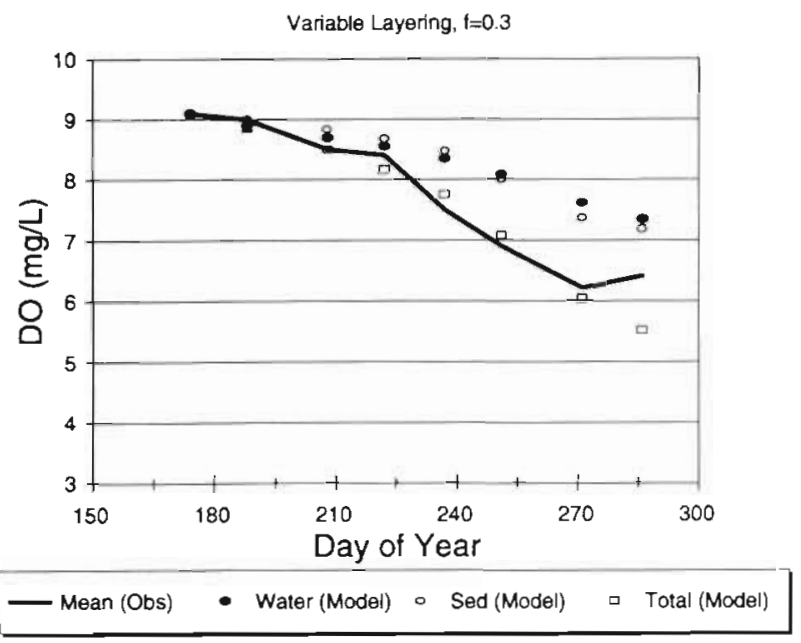

Fig. 7. Model partitioning and observed DO for 1994. Total and partitioned ( $R_{\mathrm{wc}}$ and $R_{\text {sed }}$ components) decline is shown relative to mean DO concentrations at each survey

because the influence of $R_{\text {sed }}$ was reduced (Fig. 6b). Results for the variable layer, $f=0.30$ case were comparable to the (less-realistic) fixed layer, $f=0.43$ case, but the variable condition better approximated mean DO trends through the first half of the period, while it also simulated the increased DO decline observed in the latter half of the period. Model partitioning of water and sediment respiration for the variable layer, $f=0.30$ case showed that the sediment contribution can become more prominent as the pycnocline deepens (Fig. 7). Thus, the assumption on $f$ is particularly significant during the later stages of stratification, particularly as it interacts with variations in $B L$.

With the sloping topography and bathymetric irregularity of the region, it is difficult to specify conditions for $B L$ and $h$ over the entire sampling field, especially since the western half of the field destratifies earlier than the deeper eastern side. Also, the proportion of bottom type that is softer, depositional and characteristic of where benthic flux measurements were made is not known exactly but is lower (as would be $f$ ) for the eastern half of the field than the western half. Model structure manipulations (Figs. 6 \& 7) are a first element of sensitivity analysis, but we cannot fully establish the 'correct' assumptions for modeling the entire field over the entire period even though we know results are sensitive to layering and $f$. Thus, we conducted an exercise to address model sensitivity related to such physical, as well as metabolic, uncertainties (Fig. 8).

We varied $T$ and $B L$, along with the 'base' coefficients (i.e. intercept rate at $T=0^{\circ} \mathrm{C}$ ) and 'exponent' coefficients (i.e. $T$ multiplier) of the $R_{\mathrm{wc}}$ and $R_{\text {sed }}$ functions (Table 1 ), each nominally by $\pm 20 \%$. Coefficients

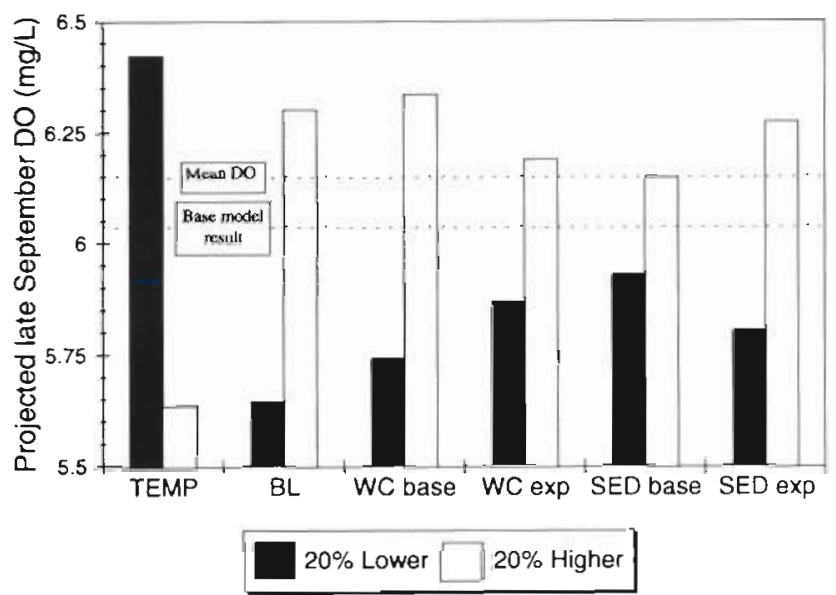

Fig. 8. Sensitivity analysis using the 1994 DO decline model. Selected parameters were varied $\pm 20 \%$ of their values for a standard condition (see text), with the DO concentration attained in late September 1994 shown for comparisons. Measured temperature (TEMP, by survey), the estimated thickness of the bottom layer $(B L$, from density profiles each survey), and $a$ and $b$ terms of water column and sediment respiration rate functions (Table 2) were varied. The observed mean $( \pm \mathrm{SD})$ DO concentration of $6.15( \pm 0.53) \mathrm{mg} \mathrm{l}^{-1}$ for September 1994 is indicated, as is the result for the standard model condition $\left(6.04 \mathrm{mg} \mathrm{l}^{-1}\right)$

for metabolic functions were merely lowered or raised by $20 \%$. For $T$ and $B L$, the range was created by multiplying data for each survey by 0.8 or 1.2 . The designation '20\% Lower' means a lower $T$, lower values of metabolic function coefficients, and a lower value (thinner layer) for $B L$. For reference, a $20 \%$ lower $T$ in late September (e.g. $10.2^{\circ} \mathrm{C}$ vs measured mean of $12.8^{\circ} \mathrm{C}$ in 1994 ) is smaller than the difference measured in near-bottom temperature means for late September of different years (Table 3 ), and a $20 \%$ variation in $T$ was often characteristic across the sampling grid within a survey. Each model run computed the DO concentration at Day 270 (late September), the time of the annual survey-mean minimum DO concentration in 1994 (see Fig. 6). Model predictions compare results with the 'base model' result (variable layering, $k=0.1$, $f=0.30$; shown in Fig. 6b) and observed mean DO concentration; for each comparison only the indicated parameter was varied from the base model.

The largest range in the $( \pm 20 \%$ ) predictions (Fig. 8) was noted for $T\left(0.8 \mathrm{mg} \mathrm{l}^{-1}\right)$; all conditions produced concentrations within $0.4 \mathrm{mg} \mathrm{l}^{-1}$ of the base model. Effects of changes in $B L$ were within $\geq 0.25 \mathrm{mg} \mathrm{l}^{-1}$ of the base model. Sensitivity to the base coefficient for $R_{w c}$ was similar to $B L$, but variations in the other metabolic coefficients produced changes that were $<0.25 \mathrm{mg} \mathrm{l}^{-1}$ of the base result. In a separate run (not shown), we determined that effects of $T$ and $B L$ were almost additive when the two were varied simultaneously. 


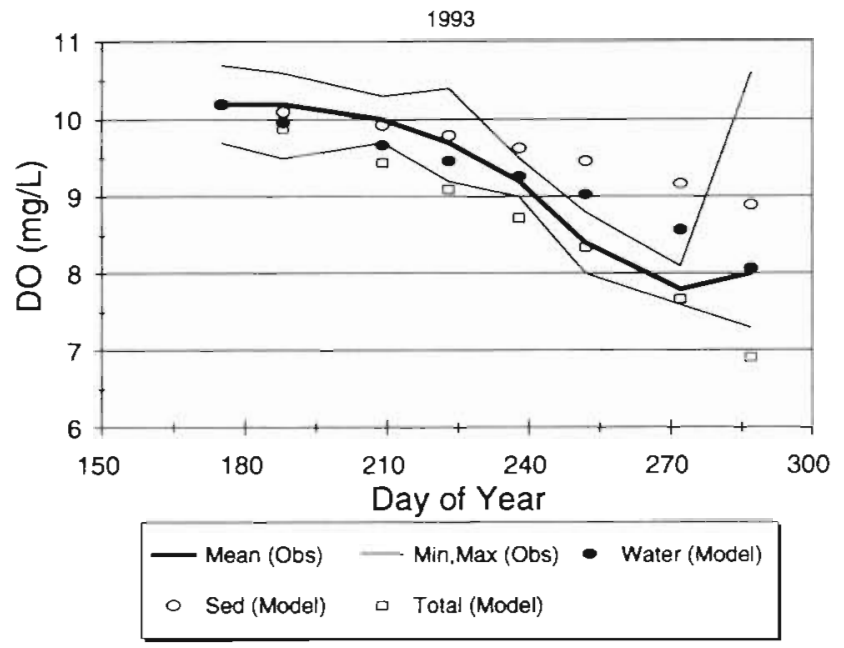

Fig 9. Do decline model projection with partitioning for 1993 conditions compared to 1993 observations. Total and partitioned ( $R_{w c}$ and $R_{\text {sed }}$ components) decline is shown relative to mean DO, minimum, and maximum concentrations by survey

Given the $T$ and $B L$ sensitivities, it was of interest as a final exercise to apply the modeling approach developed for 1994 data to predict DO in the different physical setting of 1993. In contrast to 1994, the pycnocline in 1993 was fairly constant through the period of stratification, centered at about 15 to $20 \mathrm{~m}$, and did not deepen dramatically in September. Bottom-water temperatures were generally lower in 1993 than 1994 (Table 3), so model metabolic demands were reduced compared to 1994 . On the basis of the above model manipulations, $T$ and $B L$ features for 1993 are, in principle, consistent with the observation of an annual DO minimum for $1993>1994$ (Table 3). Using the model to predict the 1993 DO decline we used the variable layering and $f=0.30$ model structure and 1993 monitoring data for $D O_{1}, T, F l u, h, B L$, and $D O_{\text {surf }}$ conditions (cf. Table 3). Model results for 1993 (Fig, 9) imply a certain robustness to the model. Model and data were in relatively close agreement near the end of the period of stratification ( Day 270, late September) and the 1993 model results mimicked interannual trends in the data (e.g. -7.75 vs $6.04 \mathrm{mg} \mathrm{l}^{-1}$ was observed in late September of 1993 and 1994, respectively; cf. Figs. $9 \& 7$ ). Compared to observations the 1993 model predictions were slightly low during the early-mid part of stratification; one potential cause for this result is discussed below. Interestingly, the 1993 model results suggested $R_{\mathrm{wc}} \geqslant R_{\text {sed }}$ for the period (Fig, 9), a contrast to 1994 results (Fig. 7). Dominance of $R_{w c}$ in the 1993 model prediction can be attributed primarily to a relatively constant and thick $B L$ compared to 1994 .

\section{DISCUSSION}

Low DO conditions have long been recognized in enclosed fjords and basins with restricted flows (e.g. Richards 1965). There are many recent examples of stratified shelfwaters, estuaries, and enclosed seas that have experienced hypoxia or anoxia (e.g. Long Island Sound [Parker \& O'Reilly 1991], NY Bight [Falkowski et al. 1980], Mobile Bay and the Gulf of Mexico [Turner et al. 1987, Rabalais et al. 1996], Chesapeake Bay, [Officer et al. 1984], Pamlico Bay [Stanley \& Nixon 1992], as well as the Kattegat and the Baltic Sea [e.g. Kullenberg 1986, Larsson et al. 1985, Rosenberg et al. 1990]). The shallow inner shelf waters of western Massachusetts Bay did not, in the early 1990s, have a significant concern with respect to DO. Monitoring results demonstrated that bottom waters in western Massachusetts Bay regularly experienced a decline in DO concentration during seasonal stratification, but DO rarely fell below $5 \mathrm{mg} \mathrm{l}^{-1}$ and did not approach hypoxia $\left(<2 \mathrm{mg} \mathrm{l}^{-1}\right)$. Nonetheless, DO concentrations varied spatially and temporally and in 1994 reached much lower levels than in 1992 or 1993 - all facts which facilitate addressing our central question of how various factors contribute to DO decline and annual near-bottom DO minima. The modeling results also help identify sensitivity of near-bottom DO decline to physical (and climatically influenced) variability, within and between years. From monitoring and modeling results, the roles of metabolism, $T$, and dynamics of stratification are explored and briefly compared to findings for other areas.

\section{Inferences on metabolic and physical factors}

\section{Production-respiration trends}

Modeling analyses were conducted with metabolic functions essentially fixed within each year. Across years, model comparisons had minor differences in $R_{\text {sed }}$ and $R_{\mathrm{wc}}$ driven by differences in in situ conditions ( $T$ and Flu, Table 1). The formulation for $R_{w c}$ may change with different biology, but we have no data to assess this. However, we can ask if there is evidence on the role of variations in primary production: the question of how DO in bottom waters couples with primary production (and nutrient enrichment) is one often asked (cf. Nixon et al. 1986, Oviatt et al. 1986) because, in principle, increased metabolism creates a potential for lower DO, particularly if a system stratifies.

Net primary production (NPP, by ${ }^{14} \mathrm{C}$ method) during the 1992 to 1994 period is compiled in Table 4 for comparison with DO. 1993 had an intense fall diatom bloom with high summer and fall chlorophyll $a$. 
Arranged by annual NPP as well as autumn NPP the years ranked $92<94<93$. But, in terms of annual DO minima, 1993 had the highest, not lowest, DO minimum (e.g. $94<92 \leq 93$, Table 4 ). Using summer NPP (Table 4), the ranking was $94<92<93$ which is the exact opposite of the expectation if NPP during stratification were the primary determinant of bottom-water DO (cf. Hargrave \& Phillips 1986). Studies in shallower coastal marine ecosystems support the notion that a spring bloom deposits a pulse of organic matter to bottom sediments where it is consumed as the near-bottom waters rapidly warm in spring and summer (e.g. Nixon et al. 1980, Graf et al. 1982, Rudnick \& Oviatt 1986). In our stratified shelfwater case, bottom-water warming is slow and $T$ only exceeds $8^{\circ} \mathrm{C}$ by early fall. Spring chlorophyll a (mean and maximum) and NPP (with some overlap of estimates) had the relative ranking $93 \leq 92<94$ (Table 4); therefore, inter-annual trends are consistent with the notion of a 'lagged' connection between the intensity of the spring bloom and the later depression of DO concentrations in bottom waters. However, field metabolism data were not consistent with a 'lagged' concept because sediment respiration was measurably higher in late summer 1993 (than 1994, Giblin et al. 1995), when spring chlorophyll and production were lower (Table 4). The high 1993 sediment respiration (even despite a relatively low temperature, Table 4) instead suggested a rapid response to high 1993 summer/fall production and recent (vs lagged) organic deposition (Kelly \& Nixon 1984). Even though there appeared a benthic respiration stimulation 'event' in 1993, the DO trends show that such an event does not necessarily produce markedly low bottom-water DO. In general, simple and consistent metabolic-DO linkages are not strongly evident from the data, leading to the obvious conclusion that other factors besides respiratory demands are significant.

\section{Other potential primary production effects: an unmodeled biological factor}

In a substantial fraction of the study area, there is cobble and boulder hard bottom. Benthic algae (including encrusting coralline species and Agarum cribosum, shotgun kelp) are found, some to at least $35 \mathrm{~m}$ depth (e.g. Pandan 1977, Coats et al. 1995). We have no data on benthic productivity, which in principle could moderate rates of bottom-water decline by adding DO. Faunal and floral distributions in the hardbottom environments are patchy; it does not seem likely that attached algae would strongly influence DO in bottom waters throughout the whole region but it remains an unknown. On the other hand, DO from

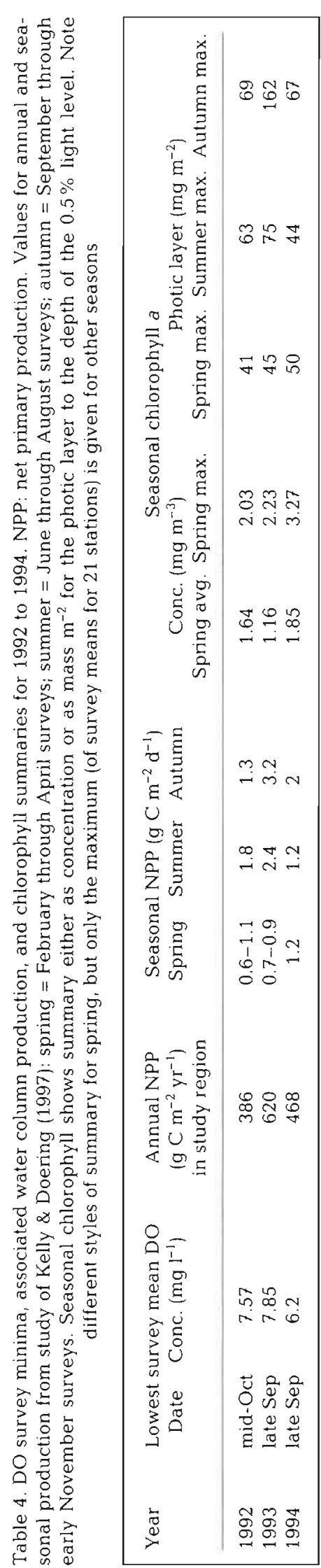


mid-water pelagic productivity could add to bottomwater concentrations. For example, a 'rebound' in bottom-water DO concentrations between spring and early summer was notable in 1992 (Fig. 3, Day 140 to 180). This progression contributed to differences between $D O$ levels at the 'start' of summer stratification in June 1992 versus June 1994 (Fig. 5, Table 3). In June 1992, a substantial mid-depth concentration of a dinoflagellate Ceratium longipes was in progress (Kelly et al. 1993), accompanied by a mid-depth DO maximum which may have infused some DO into the bottom layer

A calculation regarding mid-water production is illustrative; we used ${ }^{14} \mathrm{C}$ measurements for an early summer situation (Kelly et al. 1995a). The photic zone at Stn N16P near the center of the field (Fig. 1) was $\geq 25 \mathrm{~m}(\sim 42 \mathrm{~m}$ total water depth) and production occurred below the sharp thermocline (found at 5 to $10 \mathrm{~m}$ depth) into subpycnocline bottom waters. Production was -10 to $15 \mu \mathrm{g} \mathrm{C} \mathrm{l}^{-1} \mathrm{~h}^{-1}$ for a subsurface chlorophyll a maximum layer -2 to $8 \mathrm{~m}$ thick and as deep as 20 to $21 \mathrm{~m}$. Assuming a $P Q \sim 1$ (Kelly \& Doering 1997), net production of DO was 0.027 to $0.04 \mathrm{mg}$ $\mathrm{l}^{-1} \mathrm{~h}^{-1}$, or $\sim 0.2$ to $0.48 \mathrm{mg} \mathrm{l}^{-1} \mathrm{~d}^{-1}$ during daylight. Assuming about $50 \%$ of daytime production was respired at night (respiration was $\sim 0.006$ in mid-water to $0.02 \mathrm{mg} \mathrm{l}^{-1} \mathrm{~h}^{-1}$ in the upper layer, Kelly et al. 1995a), there would be $\sim 0.03$ to $0.08 \mathrm{mg} \mathrm{I}^{-1} \mathrm{~d}^{-1}$ added to the entire bottom layer ( $15 \mathrm{~m}$ thick) by a $5 \mathrm{~m}$ productive layer and on a $24 \mathrm{~h}$ basis. The calculated rate is comparable in magnitude to DO decline rates (Table 3 ) and could therefore moderate DO (cf. Fig. 4, 1992 to 1994), especially if mid-water production were spatially extensive, prolonged, and/or more intense than assumed here. Although difficult to measure at proper scales and to model without adding a lot of complexity (light, nutrients, plankton), mid-water production has some potential to affect DO concentrations in bottom water.

Temperature effects on respiration

The most obvious physical difference across years was a higher bottom-water temperature in 1994, coincident with lowest measured DO concentrations. Mean temperatures for June 1994 were within $1.5^{\circ} \mathrm{C}$ of June in other years (e.g. $6.1^{\circ} \mathrm{C}$ in 1994 vs $5.3^{\circ} \mathrm{C}$ in 1993), but were $\geq 4^{\circ} \mathrm{C}$ higher than other years in late September/October (Table 3). Based on metabolic $\mathrm{Q}_{10} \mathrm{~s}$ (water and sediment) -23 to $41 \%$ higher DO respiration rates are predicted with a $4^{\circ} \mathrm{C}$ difference, everything else being equal. DO decline towards the end of stratification and at higher $T$ ranged from a low rate of $0.033 \mathrm{mg}$ $\mathrm{l}^{-1} \mathrm{~d}^{-1}$ (1992) to a high of $0.046 \mathrm{mg} \mathrm{l}^{-1} \mathrm{~d}^{-1}$ (1994)
(Table 3); the 1994 decline was $39 \%$ faster than 1992, but only $-15 \%$ faster than 1993 . Therefore, interannual differences in DO decline could be accounted for solely by $T$ effects on respiration. On the other hand, one can also look at intra-annual trends, such as when bottom-water $T$ rose more than $4^{\circ} \mathrm{C}$ from June to September 1994. The DO decline from early August to late September $\left(0.046 \mathrm{mg}^{-1} \mathrm{~d}^{-1}\right.$; average $T$ : $\left.11^{\circ} \mathrm{C}\right)$ was $300 \%$ the decline from June to early August $10.015 \mathrm{mg}$ $\mathrm{l}^{-1} \mathrm{~d}^{-1}$; average $T$ : $7^{\circ} \mathrm{C}$ ) (Table 3 ). This intra-annual trend cannot be explained solely by a $T$-respiration effect, so there must be additional contributing factors.

\section{Effects of stratification}

At a late-season decline of $0.046 \mathrm{mg} \mathrm{DO}^{-1} \mathrm{~d}^{-1}$, it obviously matters if a stratification period is prolonged in autumn; 11 more days could mean an additional $0.5 \mathrm{mg} \mathrm{l}^{-1}$ decrease. However, for the 1992 to 1994 period, the lowest annual DO minimum did not occur later in 1994 than in other years. Judging from differences in density (surface vs bottom $\sigma_{T}$, e.g. Fig. 2), stratification may have been initiated earliest in 1994. But for several reasons, the duration of stratification per se was not the principal reason for the difference between years and duration of stratification is not the reason for the increased decline later in the period of 1994. Instead, both field and modeling results corroborate that late-season deepening of the pycnocline was a strong contributing factor to the low DO observed in 1994. Inspection of individual profiles and cross-field transects (e.g. Fig. 5) consistently revealed lowest DO concentrations at locations where the pycnocline was deep and the resultant bottom-water layer was thin. The pycnocline deepening, along with higher bottom $T$, was most pronounced in profiles of 1994 surveys in late September (e.g. Fig. 2). Moreover, modeling demonstrated that one can sharply speed up the nearbottom water's DO decline (above that expected by $T$ alone) if one thins $B L$.

\section{An unmodeled physical factor}

Torgersen et al. (1997) suggested that physical transport (horizontal and vertical) is influential on subpycnoline DO in eastern Long Island Sound (cf. Parker \& O'Reilly 1991, Welsh \& Eler 1991). We did not include horizontal transport as a model term (Eq. 1); calculations provide an order of magnitude estimate of this process. In 1994 a bottom-water salinity increase occurred during stratification, which could only arise from intrusion of deeper water upslope into the sampling field. Mean bottom-water salinity was significantly 
higher in late September/October than in June/early July (mean $=32.23$ vs 32.06 PSU) and almost always was significantly higher for deeper eastern stations than shallower western stations (paired $t$-test, $p<0.05$ ). The salinity gain ( 0.17 PSU) can be produced by mixing study area and deeper offshore waters 50:50, implying replacement of about $50 \%$ of the bottom water during the period. Gradual intrusion (on average, about $50 \%$ of the $10 \mathrm{~km}$ length of the field from east to west, over about $100 \mathrm{~d}$ ) might be $-50 \mathrm{~m} \mathrm{~d}^{-1}\left(=0.05 \mathrm{~cm} \mathrm{~s}^{-1}\right)$. USGS mooring studies (United States Geological Survey, Woods Hole, unpubl.) suggest that bottom waters of the study area undergo little net advection over days to weeks in summer. Compared to a semi-diurnal tidal excursion $\sim 2 \mathrm{~km}$ and near-bottom tidal velocities at $\sim 30 \mathrm{~m}$ up to 10 to $15 \mathrm{~cm} \mathrm{~s}^{-1}$ (R. Geyer, in Kelly et al. $1995 b)$, the advection suggested by our rough calculation would probably be difficult to note. More importantly, offshore waters had DO concentrations not different from stations in the eastern (offshore) half of the study area during June to October 1994 and offshore DO concentrations were alternately lower, higher, or similar to the shallower western half of the study area depending on the survey (paired $t$-tests at $p=0.05$ ). A calculation using the largest DO concentration difference $\left(\sim 0.5 \mathrm{mg} \mathrm{l}^{-1}\right)$ in late summer (mixed 50:50 with resident water over $30 \mathrm{~d}$ ) implies DO addition to the study area of $\sim 0.008 \mathrm{mg} \mathrm{l}^{-1} \mathrm{~d}^{-1}$. This rate is small compared to season-long decline rates (Table 3 ) and also compared to potential additions of mid-water production (above), even though it exceeds model estimates of vertical diffusive input of DO. While not a comprehensive assessment, brief consideration suggests that horizontal transport was neither a consistent nor strong moderating feature for the stratified period of 1994.

\section{Seasonal pycnocline deepening in western Massachusetts Bay}

Results indicate temporal variability in the influence of stratification on bottom-water DO. The pycnocline, controlled by temperature in this setting, is sharp within the surface 10 to $15 \mathrm{~m}$ (cf. Fig. 2) during early summer. At this time, the photic zone can be within the lower pycnocline/upper bottom water (Fig. 10), which avails autotrophic plankton the principal source of dissolved nutrients at that time of year (the bottom water). Thus, there is potential in early summer for mid-water production to infuse DO into the bottom layer and moderate the ultimate DO minimum reached later in the season. Such a process would partially disconnect spring bloom dynamics from subpycnocline DO levels, and is contrary to the concept of a seasonally isolated bottom layer only influenced by continued hetero-

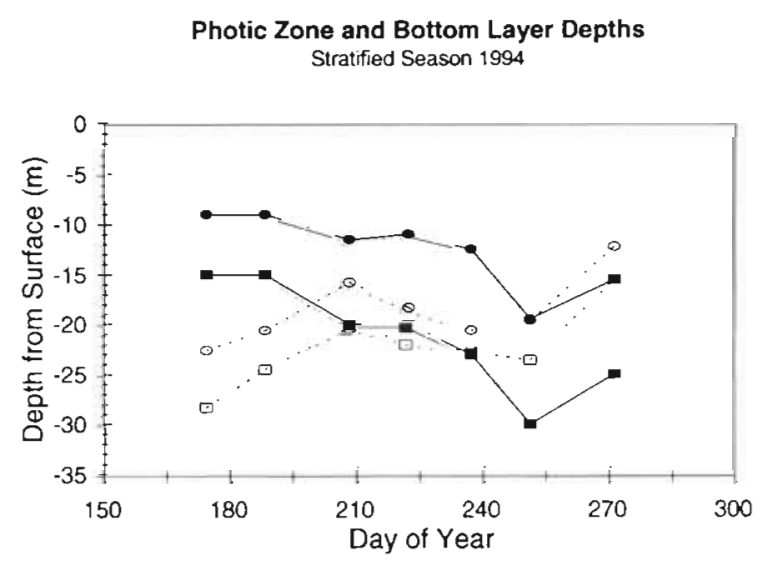

- Top of BL

- Mid-pyenocline $\square \quad$ Photic $0.5 \%$

- Photic $1 \%$

Fig. 10. Stratification in relation to the depth of the photic zone over the summer stratified season of 1994 . A mid-pycnocline depth and the depth at which a distinct bottom layer became evident were estimated from vertical density profiles data show the seasonal deepening and were used in modeling. The $0.5 \%$ and $1 \%$ light levels (as measures of the photic zone) tend to rise over the stratified season (from data of Kelly \& Doering 1997)

trophic consumption. The depth of the photic zone relative to the surface mixed layer, often examined in relation to spring bloom dynamics, may be significant in summer also with respect to bottom-water DO.

By late summer in western Massachusetts Bay (Fig. 10), the pycnocline deepens (cf. Fig. 2) and the photic zone is confined to the surface mixed layer, so that autotrophic DO can be infused only indirectly, by the slower process of gradient-driven vertical diffusion across the pycnocline (i.e. the $F_{\mathrm{d}}$ term of the model). As bottom-water $T$ characteristically rises late in the stratified period, metabolism in the heterotrophic bottom water and underlying sediments increases. Concurrent with a $T$ increase, the pycnocline in some years may deepen dramatically and occasionally produce a thin near-bottom layer across some of the field. Deepening of the pycnocline and consequent thinning of the bottom layer at this time accelerates the late-period DO decline above and beyond the acceleration due to increased temperature-respiration effects. A resultant DO depletion effect comes from enhanced contribution of $R_{\text {sed }}$ as the volume of enclosed overlying bottom water is reduced, a phenomenon akin to the effect of enclosing a small volume of water in an in situ chamber in order to measure benthic fluxes.

Bottom-water variability during the critical late-season period appears related to bathymetry in 2 ways: at the regional scale, as a consequence of the general slope from inshore to offshore, and at a more local scale, as a consequence of irregularity in bathymetry 
throughout the field. The pycnocline intercepts the sloping topography, the location progressing seaward as the system destratifies from inshore to offshore. The pycnocline itself is interrupted by shoals or drumlins that rise above the general topography. As a consequence of these features, near-bottom DO can vary widely in autumn (e.g. Figs. $4 \& 5$ ) as parts of the field are stratified and others mixed.

\section{Stratification, DO, and a comparison to other areas}

Physical constraints on metabolism's influence on DO in coastal ecosystems have been well recognized. Among such constraints, stratification and shallowness of the water body are notable. For example, Turner et al. (1987) suggested bottom-water DO deficits for Alabama coastal systems relate to the 'strength' of stratification, i.e. the vertical difference in surface and bottom density. They, and others, have noted that, stratification being equal, shallower systems are likely to have more severe DO depletion because of generally higher sediment metabolism. Even in shallow systems, however, variations in winds, freshwater discharge and physical mixing energies may be more influential to DO trends than metabolic activity (e.g. Stanley \& Nixon 1992). Compared to areas intensively studied and reported in the literature, our case is a shelf system of intermediate depth $(20$ to $50 \mathrm{~m})$. Our study, however, presents a new case in which stratification appears influential, not by 'strength' per se, but by progressive deepening of the pycnocline - stratification through the season has potential to first moderate, then accelerate, DO decline. In some years, late season deepening temporarily creates a confined, 'shallow' near-bottom layer and briefly enhances the role of benthic activity in spite of the overall water depth.

For a system with episodic DO problems, Falkowski et al. (1980) suggested that an unusual anoxia in the shelfwaters of NY Bight south of Long Island in 1976 could have occurred without anthropogenic cause. In contrast, for a deeper, stratified, less hydrodynamically open (and longer residence time) system like the Baltic, researchers have argued that its trends of decreasing DO have occurred with relatively stable stratification and thus are less due to physical variability than to documented increases in nutrients and productivity (e.g. Larson et al. 1985, Kullenberg 1986, Rosenberg et al. 1990). Similarly for the mid-portion of Chesapeake Bay (20 to $40 \mathrm{~m}$ ), Officer et al. (1984) stressed the significance of increasing nutrient inputs and productivity (vs freshwater discharge, a stratifying feature), as well as the relative prominence of benthic respiration in contributing to anoxia. Even for the Chesapeake, considerable covariability in DO with physical processes also has been noted; in particular, horizontal DO variability in shallow areas has been related to wind-induced tilting and oscillations of the pycnocline (e.g. Breitburg 1990, Sanford et al. 1990). Our study provides a different case yet (and one without hypoxia to date), where thermocline deepening, not horizontal excursions, can cause considerable bottom-water DO variability even without obvious linkage to anthropogenic forcing (e.g. nutrient loads or productivity). Falkowski et al. (1980) show a time series covering most of this century to suggest that lower DO concentrations in the NY Bight coincide with higher bottom-water temperature. Our 3 yr time series is insufficient to explore such trends; nonetheless modeling analyses indicate sensitivity to physical effects of temperature and variability in vertical structure.

\section{Lessons and limitations}

Our study establishes factors influential to DO in a shelfwater region where a new outfall will soon discharge. Results highlight that monitoring should continue to measure physical structure, light, chlorophyll, and respiration at sufficient detail to describe dynamics; if this is done properly, effects and cause are likely to be resolvable. This principal lesson brings additional focus on what detail is 'sufficient.' To begin, our model's $f$ assumption and subpycnocline NPP rates are important to results but it is difficult to improve precision in these parameters without further data. Critical elements identified by sensitivity analyses included $T$, $B L$, and coefficients of metabolic functions (Fig. 8). Among the most model-sensitive, $T$ is by far the easiest to monitor with precision, whereas $B L$ is difficult to characterize. Vertical structure varies widely over days and with tides and is usually quite variable at any given time over the region of the 21 sampling stations. Moreover, many vertical profiles do not sharply identify upper and lower layers and pycnocline, so vertical structure characterization $(B L$ and $h$ ) remains semisubjective even though model comparisons clearly demonstrate the influence of vertical layering. In terms of metabolism, respiration functions for modeling could be improved with more extensive measurements.

Besides precision concerns, an improved DO decline model would have a greater degree of dynamism to more accurately model conditions across the whole study area, even though the range of DO concentrations at any one time can be easily modeled by timespace variability in assumptions. As examples, the eddy diffusion coefficient $k$ and sediment extrapola- 
tion factor $f$ (a large uncertainty) probably should vary through the stratified period and almost certainly should vary across space. The shallower side of the field has the highest proportion of the depositional sediments and this area also destratifies earlier, so the $k$, $B L, f$ parameters (Table 1) in principle should be changed to model each region separately during this critical period. Model runs with variations in $h, B L, k$, $R_{\mathrm{wc}}$ (including $T, F l u$, and the unassessed effect of organic quality on respiration) and $R_{\text {sed }}$ (including $T, f$ ) produce the dispersion noted around mean DO concentrations (e.g. Fig. 4) and this observation reinforces the point that 1 set of average conditions is insufficient to model each location of the field all at once. Given the model sensitivity and environmental variability now documented, a model grid could be much smaller; without additional data, we do not have strong empirical basis for time-space model variance other than that already specified and cannot improve confidence in predictions. On the other hand, given that conditions for 1 or more functions or their associated terms vary by $20 \%$ or more across the study area at most times, trying to improve on the precision of functions may be unnecessary if the goal of modeling relates to average conditions of the area. A lesson for monitoring is to define the scale(s) at which conditions need to be known for management purposes.

Finally, the frequency of sampling will affect results. Repeated sampling of stations over several days revealed substantial variability in in situ bottom-water conditions, likely due to tidal aliasing. Kelly et al. (1995b) noted tidal effects at stations including N10P, which is shallow and in the midst of irregular bathymetry. The irregular bathymetry can make repeated sampling at the same height above bottom difficult, yet minor variations $( \pm 1 \mathrm{~m})$ in sampling position will alter results at the critical season when $B L$ is small, nearbottom temperature is high, sediment-water boundary gradients sharp and confounded by tidal effects. Moreover, surveys are separated by a few weeks within the fall period, and there is no reason to think the annual minimum is actually measured each year, nor that data for each year are consistent with respect to timing of surveys and minima. A continuous near-bottom mooring with in situ sensors would help resolve timing issues, but with cross-field heterogeneity there will always be spatial extrapolation uncertainty. We do not offer resolution for each of these issues, but efforts to detect a specific level of change and ascribe cause must remain conscious of these inherent observational uncertainties.

Acknowledgements. Monitoring was supported by the Massachusetts Water Resources Authority (MWRA), which maintains a publicly available report series, available from Mrs
Bernadette McCarthy, Environmental Quality Department, Massachusetts Water Resources Authority, Boston, MA 02129, USA (see also http://www.mwra state.ma us/harbor/enquad/). Field sampling was conducted by individuals from the University of Rhode Island (Narragansett, RI), Battelle Ocean Sciences (Duxbury, MA), Ecosystems Center (Marine Biological Laboratory (MBL), Woods Hole MA) and the University of Massachusetts at Dartmouth. The authors directed these studies while at Battelle and the University of Rhode Island, respectively. Thanks especially to Carl Albro, Chip Ryther, Deb West, Paul Dragos, Laura Reed, Edwin Requintina, Bob Vaillancourt, and many others who labored to produce the set of $\mathrm{DO}$ and water column data summarized in this paper. Anne Giblin and colleagues at MBL conducted the benthic flux studies. Study conclusions represent the effort and perspective of the authors and do not necessarily represent the opinion or perspective of the MWRA.

\section{LITERATURE CITED}

Albro CS, Kelly JR, Hennessy J (1993) Combined work/quality assurance project plan for baseline water quality monitoring. MWRA Environ Quality Dept Misc Rep No Ms-14. Massachusetts Water Resources Authority, Boston

Borland (1993) User's guide, version 50, Quattro Pro for Windows. Borland International, Inc, Scotts Valley, CA

Breitburg DL (1990) Near-shore hypoxia in the Chesapeake Bay: patterns and relationships amoung physical factors. Estuar Coast Shelf Sci 30:593-609

Coats DA, Imamura E, Campbell JF (1995) Hard-substrate reconnaissance survey $\$ 9404$ final analysis report. MWRA Environ Quality Dept Tech Rep Ser No 95-1. Massachusetts Water Resources Authority, Boston

Doering PH (1989) On the contribution of the benthos to pelagic production. J Mar Res 47:371-383

Falkowski PG, Hopkins TS, Walsh JJ (1980) An analysis of factors affecting oxygen depletion in the New York Bight. J Mar Res 38(3):479-506

Fofonoff, NP, Millard RC Jr (1983) Algorithms for computation of fundamental properties of seawater. UNESCO Tech Pap Mar Sci 44

Graf G, Bengtsson W, Diesner U, Schulz R, Theede H (1982) Benthic response to sedimentation of a spring phytoplankton bloom: process and budget. Mar Biol 67:201-208

Geyer WR, Gardner GB, Brown WS, Irish J, Butman B, Loder T, Signell R (1992) Physical oceanographic investigation of Massachusetts and Cape Cod bays. Final Report to Massachusetts Bays Program (MBP-92-03), Boston

Giblin AE, Hopkinson CS, Tucker J, Nowicki B, Kelly JR (1994) Metabolism, nutrient cycling and denitrification in Boston Harbor and Massachusetts Bay sediments in 1993. MWRA Environ Quality Dept Tech Rep Ser No 94-5. Massachusetts Water Resources Authority, Boston

Giblin AE, Hopkinson CS, Tucker J, Nowicki B, Kelly JR (1995) Metabolism, nutrient cycling and denitrification in Boston Harbor and Massachusetts Bay sediments in 1994. MWRA Environ Quality Dept Tech Rep Ser No 95-13. Massachusetts Water Resources Authority, Boston

Giblin AG, Hopkinson CS, Tucker J (1997) Benthic metabolism and nutrient cycling in Boston Harbor, Massachusetts. Estuaries 20(2):346-364

Golden (1994) Surfer for Windows. User's guide. Golden Software, Inc. Golden, CO

Hargrave BT, Phillips GA (1986) Dynamics of the benthic food web in St Georges Bay, southern Gulf of St Lawrence. Mar Ecol Prog Ser 31:277-294 
Kelly JR (1997) Nitrogen flow and the interaction of Boston Harbor with Massachusetts Bay. Estuaries 20(2):365-380

Kelly JR, Doering PH (1995) Nutrient issues update 1995 : metabolism in Boston Harbor, Massachusetts and Cape Cod Bays, MA (USA) during 1992-1994. MWRA Environ Quality Dept Tech Rep Ser No 95-19. Massachusetts Water Resources Authority, Boston

Kelly JR, Doering PH (1997) Monitoring and modeling primary production in coastal waters: studies in Massachusetts Bay 1992-1994. Mar Ecol Prog Ser 14:155-168

Kelly JR, Nixon SW (1984) Experimental studies of the effect of organic deposition on the metabolism of a coastal marine bottom community. Mar Ecol Prog Ser 17: $157-169$

Kelly JR, Albro CS, Doering PH, Foster K, Hennessy J, Reed $L_{1}$ Requintina E (1993) Water column monitoring in Massachusetts and Cape Cod bays: annual report for 1992. MWRA Environ Quality Dept Tech Rep Ser No 93-16. Massachusetts Water Resources Authority, Boston

Kelly JR, Libby PS, Albro CS, Hennessy, JT, Turner J, Borkman D, Reed L, Vaillancourt R, Heil C (1995a) Water quality monitoring in Massachusetts and Cape Cod Bays: June and July 1994. MWRA Environ Quality Dept Tech Rep Ser No 95-3. Massachusetts Water Resources Authority, Boston

Kelly JR, Albro CS, Geyer R (1995b) High-resolution mapping studies of water quality in Boston Harbor and Massachusetts Bay during 1994. MWRA Environ Quality Dept Tech Rep Ser No 95-22. Massachusetts Water Resources Authority, Boston

Knebel HJ (1993) Sedimentary environments within a glaciated estuarine-inner shelf system: Boston Harbor and Massachusetts Bay. Mar Geol 110:7-30

Kullenberg G (1986) The Baltic Sea: conditions and options of management. In: Kullenberg G (ed) The role of the oceans as a waste disposal option. NATO ASI series, D Reidel, Dordrecht, p 325-345

Larsson U, Elmgren R, Wulff F (1985) Eutrophication and the Baltic Sea: causes and consequences. Ambio 14(1):9-14

Nixon SW (1995) Coastal marine eutrophication: a definition, social causes, and future concerns. Ophelia 41:199-219

Nixon SW, Kelly JR, Furnas BN, Oviatt CA, Hale SS (1980) Phosphorus regeneration and the metabolism of coastal marine bottom communities. In: Tenore KR, Coull BC (eds) Marine benthic dynamics. University of South Carolina Press, Columbia, p 219-242

Nixon, SW, Oviatt CA, Frithsen J, Sullivan B (1986) Nutrients and the productivity of estuarine and coastal marine ecosystems. J Limnol Soc S Afr 12(1/2):43-71

Nowicki BL, Kelly JR, Requintina E, Van Keuren D (1997) Nitrogen losses through sediment denitrification in Boston Harbor and Massachuselts Bay. Estuaries 20(3): $626-639$

Officer CB, Biggs RB, Taft JL, Cronin LE, Tyler MA, Boynton WR (1984) Chesapeake Bay anoxia: origin, development and significance Science 223:22-27

Editorial responsibility: Otto Kinne (Editor). Oldendorf/Luhe, Germany
Okubo A 1971 Horizontal and vertical mixing in the sea. In: Hood DW (ed) Impingement of man on the oceans. WileyInterscience, New York, p 89-168

Oudot C, Gerard R, Morin P (1988) Precise shipboard determination of dissolved oxygen (Winkler procedure) for productivity studies with a commercial system. Limnol Oceanogr 33:146-150

Oviatt CA, Keller AA, Sampou PA, Beatty LL (1986) Patterns of productivity during eutrophication: a mesocosm experiment. Mar Ecol Prog Ser 28:69-80

Pandan JT (1977) New England Offshore Environmental Study. Final National Oceanic and Atmospheric Administration Report. US Department of Commerce, National Oceanic and Atmospheric Administration. Pacific Marine Environmental Research Laboratory, Seattle

Parker CA, O'Reilly JE (1991) Oxygen depletion in Long Island Sound: a historical perspective. Estuaries 14:248-264

Parsons TR, Maita Y, Lalli CM (1984) A manual of chemical and biological methods for seawater analysis. Pergamon Press, Oxford

Rabalais NN, Turner RE, Justic D, Dortch Q, Wiseman WJ Jr, Sen Gupta BK (1996) Nutrient changes in the Mississippi River and system response on the adjacent continental shelf. Estuaries 19(2B):386-407

Richards FA (1965) Anoxic basins and fjords. In: Riley JP, Skirrow $\mathrm{G}$ (eds) Chemical oceanography, Vol 1. Academic Press, New York, p 611-645

Rosenberg R, Elmgren R, Fleischer $S$, Jonsson P, Persson $G$, Dahlin $H$ (1990) Marine eutrophication case studies in Sweden. Ambio 19(3):102-108

Rudnick DT, Oviatt CA (1986) Seasonal lags between organic carbon deposition and mineralization in marine sediments. J Mar Res 44:815-837

Sanford LP, Sellner KG, Breitburg DL (1990) Covariability of dissolved oxygen with physical processes in the summertime Chesapeake Bay. J Mar Res 48:567-590

SAS (1988) SAS procedures guide, release 6.03 edn. SAS Institute, Inc, Cary, NC

Stanley DW, Nixon SW (1992) Stratification and bottom-water hypoxia in the Pamlico River estuary. Estuaries 15(3): $270-281$

Strickland JDH, Parsons TR (1972) A practical handbook of seawater analysis, 2nd edn. Bull Fish Res Bd Can 167

Torgersen T, DeAngello E, O'Donnel J (1997) Calculations of horizontal mixing rates using $222 \mathrm{Rn}$ and controls on hypoxia in western Long Island Sound, 1991. Estuaries 20(2):328-345

Townsend D and 8 coauthors (1991) Seasonality of oceanographic conditions in Massachusetts Bay. Technical Report No 83, October 1991 Bigelow Laboratory for Ocean Sciences. West Boothbay Harbor, ME

Turner RE, Schroeder WW, Wiseman WJ Jr (1987) The role of stratification in the deoxygenation of Mobile Bay and adjacent shelf bottom waters. Estuaries 10(1):13-19

Welsh BL, Eller FC (1991) Mechanisms controlling summertime oxygen depletion in western Long Island Sound. Estuaries 14:265-278

Submitted: February 26, 1998; Accepted: November 3, 1998 Proofs received from author(s): March 11, 1999 